\title{
Chapter 5 \\ The Present State of Traps and Fisheries Research in the Strait of Gibraltar
}

\begin{abstract}
The Strait of Gibraltar is defined as one of the most emblematic places in bluefin tuna biology, and the traps installed therein are platforms without equal in the study of this species. The enormous literature available on his fishing gear makes it impossible to make a full description from the historical point of view in the present study; however, some of the scientific activities and scientific committees of the last century are cited, followed by a list of the most recent research projects on the species. Two symposia, held in 2008 and 2011, dealing with bluefin tuna biology and fishing are reported, the latter of which was exclusively dedicated to the traps fishery and the research carried out at these fishing installations.
\end{abstract}

The Strait of Gibraltar (Fig. 5.1) is one of the most emblematic sites of the ABFT life cycle. Eastern Atlantic spawners pass through it in the boreal spring (April-June) towards the Mediterranean spawning grounds (Frade 1938; Vilela and Cadima 1961; Rodríguez-Roda 1964; Duclerc et al. 1973; Piccinetti et al. 1997; Tsuji et al. 1997; Medina et al. 2002; García et al. 2006; Suzuki and Kai 2012) and a few weeks later they swim back to the Atlantic Ocean (Rodríguez-Roda 1969a, b; Mather et al. 1995; Block et al. 2005; Medina et al. 2011; De la Serna et al. 2013; Aranda et al. 2013; Quílez-Badia et al. 2013) where they spend the rest of the year feeding intensively as far as the northernmost waters of the North Atlantic (Hamre 1960; Hamre 1965; ICCAT 1996; MacKenzie et al. 2014) at $75^{\circ} \mathrm{N}-1^{\circ} \mathrm{E}$ (De Metrio et al. 2002), or even to the western side of the Atlantic (Block et al. 2005). A part of the juveniles born at the end of spring in the western Mediterranean pass through the strait at the beginning of autumn (October), according to Rey (1979) and Rey and Cort (1986), and concentrate in wintering areas to the south of Morocco (Lamboeuf 1975; Brêthes 1978, 1979; Brêthes and Mason 1979; Rey and Cort 1986; Cort 1990).

Since ancient times ABFT has been caught using traps, a fishing gear that at first consisted of nets thrown from land, also known as traps de vista or tiro (Sañez 1791; Florido del Corral et al. 2018), as illustrated in previous pages; but nowadays traps de buche are used (Florido del Corral et al. 2018), which are made up of a complex system of chambers through which the tunas, after being guided in by kilometric long nets called raberas, the fishermen pass them from one to another until the last, or chamber of death where they are finally killed (Fig. 5.2). 


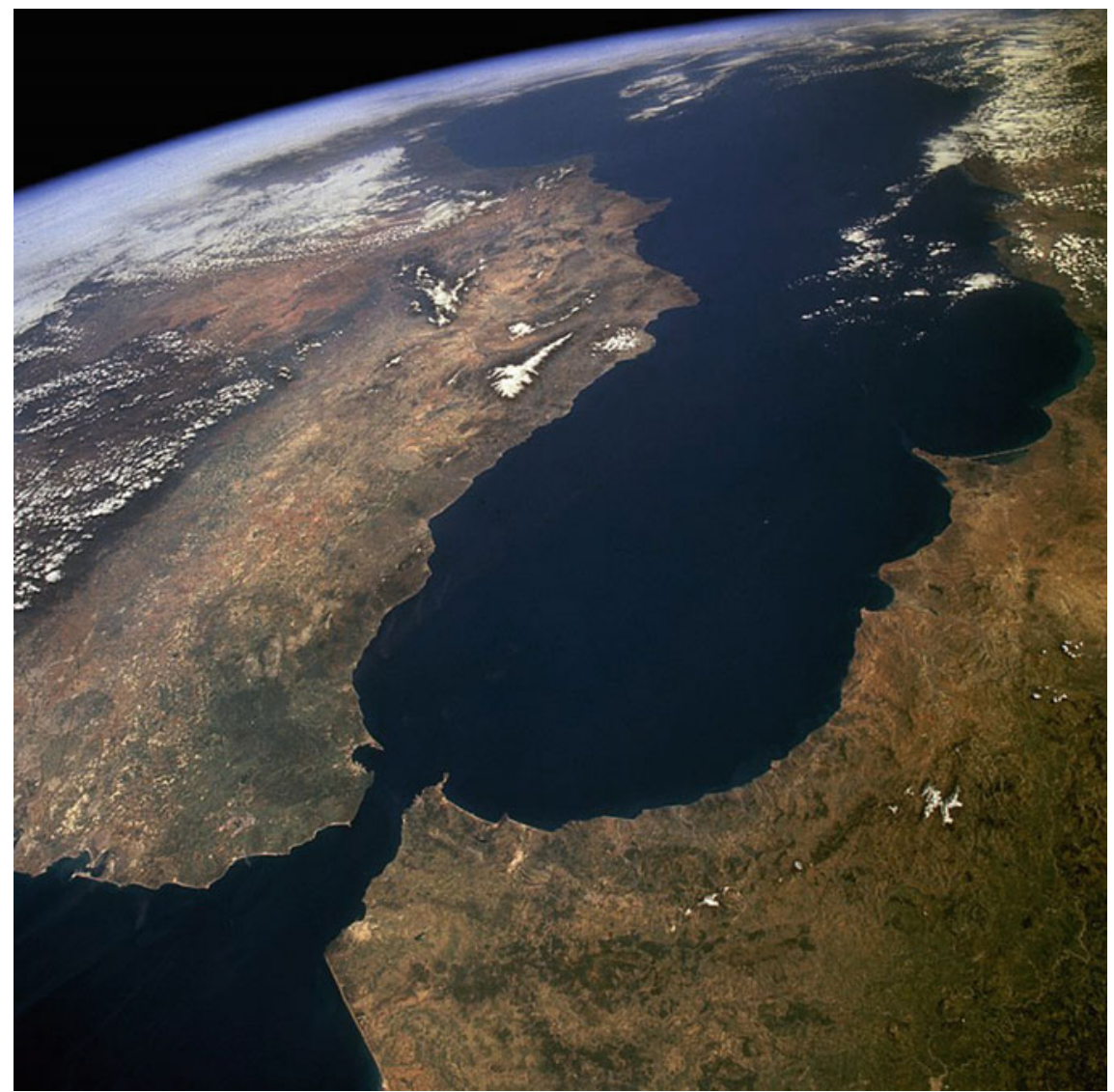

Fig. 5.1 The Strait of Gibraltar (https://en.wikipedia.org/wiki/Strait_of_Gibraltar\#/media/File: STS059-238-074_Strait_of_Gibraltar.jpg)

On the web page of the Organization of Fisheries Producers ${ }^{1}$ it says that the buche traps come from the Mediterranean and that they became consolidated on the Cádiz coasts in the last third of the nineteenth century. They describe it thus:

They are located approximately three kilometers from the coast and are more or less 34 meters deep, depending on each trap. The trap presents a complicated structure made up of a large skeleton of cables on which the nets rest, held to the bottom by means of lead weights and chains, and sustained by corks or floats in the upper part. It can be divided into two essential parts: the Catcher, mainly made up of the body of trap and the Auxiliary, which is the leader from shore to trap and the leader from offshore to trap.

ABFT fishing with traps in the Strait of Gibraltar has been the most commonly used system over the long history of this fishery (Sáñez 1791; De Buen 1925). In this

\footnotetext{
${ }^{1}$ http://fis.com/fis/companies/details.asp.
} 


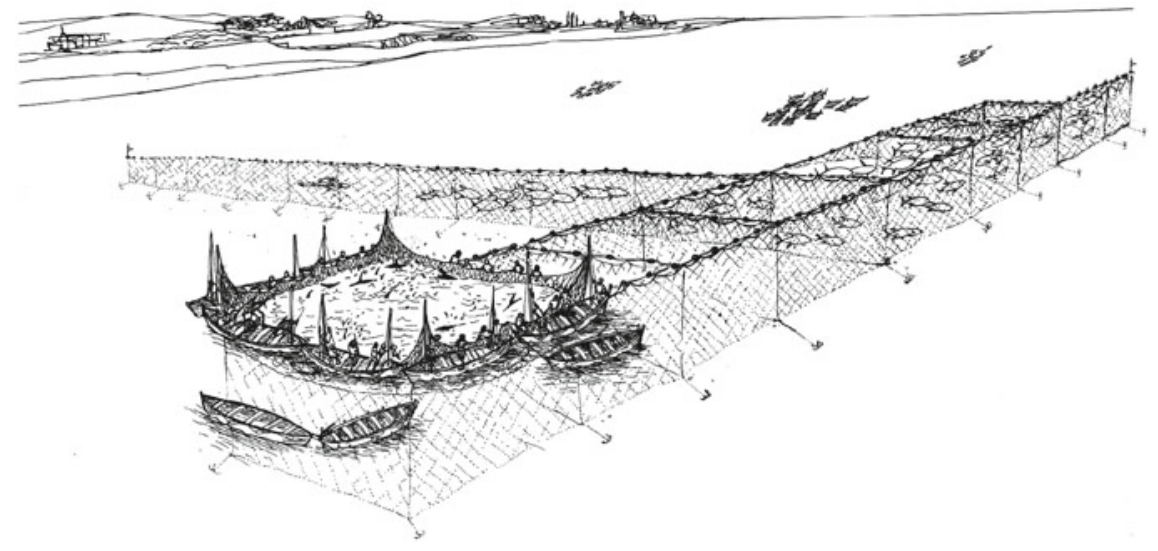

Fig. 5.2 Trap still in use (http://www.photolib.noaa.gov/bigs/fish2059.jpg)

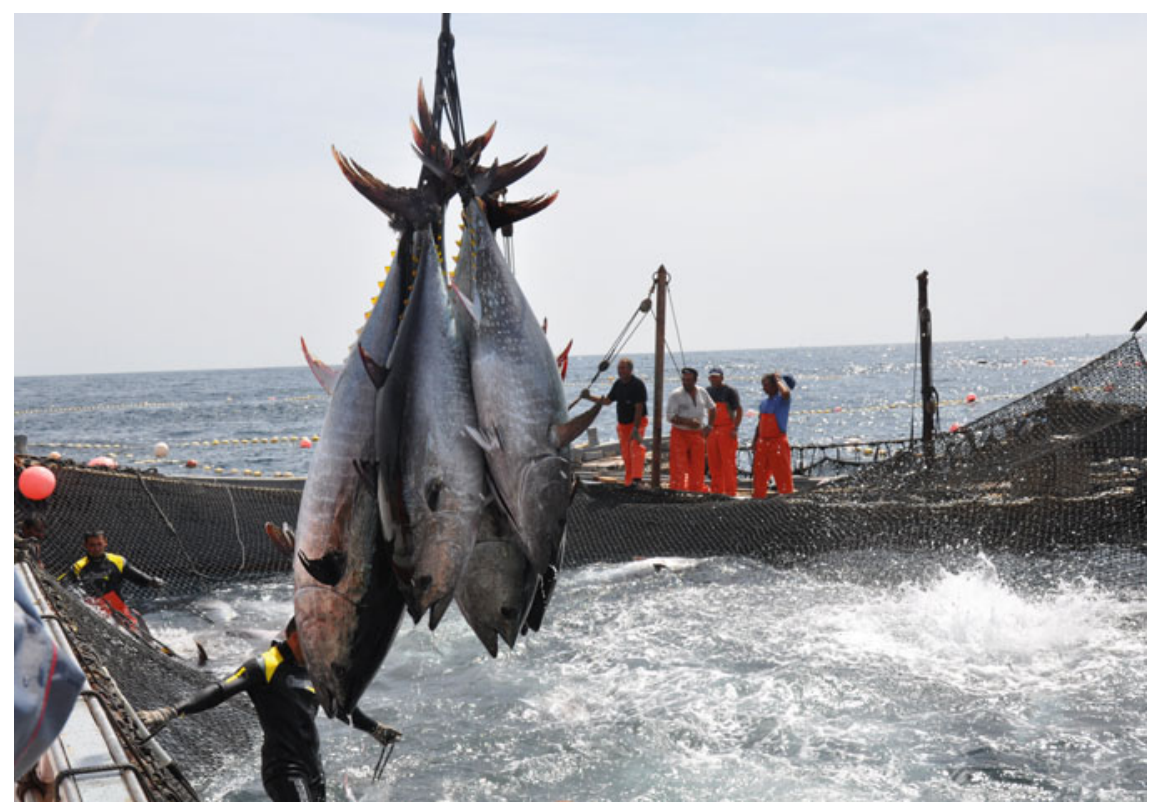

Fig. 5.3 Bluefin tuna in the spawning phase caught in the trap of Barbate, 2009 (Cádiz, Spain) (Documentary file, IEO)

area it has traditionally been used to catch spawners (Fig. 5.3) both in the spawning and the trophic phases (Lozano 1958; Rodríguez-Roda 1964, 1980; Pereira 2012).

Sella (1929), cited by Manfrin et al. (2012) first presented the existence of periodic fluctuations of 110 years in the fishing statistics of four traps of the Strait of Gibraltar and western Mediterranean Sea between 1770 and 1925. Rodríguez-Roda (1978) 
found periodic fluctuations in the catches of the traps in the south of Spain between 1929 and 1977 with maximums each 6 or 7 years. Later, in 2002, variability in the catches of eight traps in the eastern Atlantic and western Mediterranean between 1599 and 1960 was presented, revealing periodic fluctuations of 100-120 years that were inversely related to sea temperature, which may have led to variations in the migratory patterns of ABFT spawners in response to changes in oceanographic conditions (Frometin 2002).

The first research studies on tunas conducted by scientists of the Instituto Español de Oceanografía (IEO) are included in a compendium of publications entitled: "Resultados de las campañas realizadas por acuerdos internacionales" (Results of the campaigns carried out under international agreements), published between 1925 and 1927 (De Buen 1925), directed by Professor Odón De Buen (Fig. 5.4). The book is made up of several articles on the biology and fishing of bluefin tuna, Orcynus thynnus (L.) in the south of Spain signed by Fernando De Buen, then head of the Department of Biology at the Dirección General de Pesca (General Directorate of Fisheries); Luis Bellón Uriarte, assistant to the IEO, and Álvaro de Miranda y Rivera, the head of the Oceanographic Laboratory of Málaga (IEO).

These studies beautifully define the fishing activity of the traps; the landing statistics of the time and before, even those of Father Sarmiento (1525-1750), and of the tuna canning industry. All of this was accompanied by splendid illustrations by Luis Bellón as well as photographs of fishing in the traps and tuna processing at factories (Figs. 5.5 and 5.6).

According to Florido del Corral (2013): The establishment of Tuna Trap Fishing National Consortium (1928-1971) meant a commitment by the State, of a transformation of the enterprise and social organization of the Fishing Industry at the Andalusian Atlantic coasts (SW, Spain), confirming processes previously announced and inaugurating new ones. Business concentration, productive rationalization of manufacturing sites, and the consolidation of the company-towns crystallized in the central decades of 20th century, transforming traditional elements of the work cultures of the tuna fisheries, such as forms of retribution. These processes are better understood if we analyse them contextualised in the frame of power networks of the tuna fisheries oligarchy, which were characteristic in Andalusian and Spanish societies. From this holistic perspective, it is concluded the conflicting nature of the evolution of the tuna industry, between tradition and the productive rationalization.

While the Tuna Trap Fishing National Consortium was established (Ríos 2007; Florido del Corral 2013), a great deal of information was accumulated on the fishing activities and landing statistics Spanish traps, which were of great scientific value. Spanish scientists enjoyed the benefit of these advances to make their contribution to improving knowledge of tunas, mainly of ABFT.

The Spanish Civil War and the Second World War stalled the progress of non-war related scientific activities, but the end of these conflicts saw the beginning of great changes resulting from the need to find food originating from the sea for a population in great need.

In the 1950s studies of great interest were published such as that of Julio Rodríguez-Roda (Instituto de Investigaciones Pesquerasof CSIC, Cádiz), on the ABFT of the Strait of Gibraltar (Rodríguez-Roda 1957), and a voluminous study 


\section{Resultado de las campañas realizadas por acuerdos internacionales \\ bajo la dirección del \\ Prof. ODÓN DE BUEN}

Núm. 1

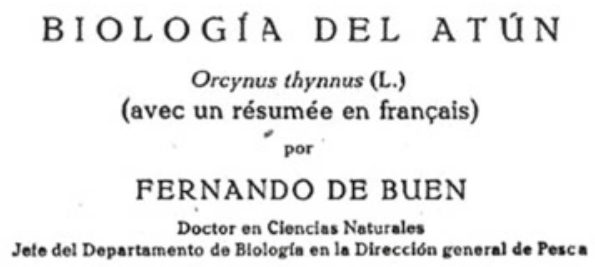

Trabajo aparecido el 20 de Junio de 1925

MADRID

Enero, 1925

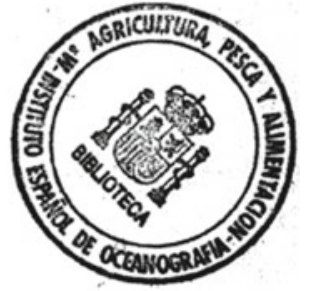

Fig. 5.4 First studies of tunas at the IEO

of the Scombrids of Spanish and Moroccan waters by Fernando Lozano Cabo (IEO), published in 1958 (Lozano 1958; Fig. 5.7).

International committees and working groups of the International Council for the Exploration of the Sea (ICES) already existed in those years (Hamre and Tiews 1963) and of the General Fisheries Commission for the Mediterranean (GFCM) (Lozano 1959) in which ABFT was studied by eminent scientists, such as Massimo Sella, Pascuale Arena and Raimondo Sarà (Italy), Fernando Frade and H. Vilela (Portugal), Henri Heldt (Tunisia-France), Jean Le Gall (France), Johanes Hamre (Norway), Klaus Tiews (Germany), Frank Mather III and Luis Rivas (U.S.A.), Akira Suda (Japan), and Julio Rodríguez-Roda and Fernando Lozano (Spain), among others.

Dr. Rodríguez-Roda retired at the beginning of the 1980s and since then scientists of the IEO have continued in their task, fulfilling the commitments acquired by Spain 
in the scientific research into this fishery. At first these were Juan C. Rey and Juan A. Camiñas, and later on José M. de la Serna, J. Ortiz de Urbina and D. Macías.

The work Rodríguez-Roda left was immense and is nowadays still fundamental to any study into the biology and dynamic of ABFT. To mention some of the studies, Figs. 5.8 and 5.9 are examples of two publications on the biology of the ABFT, but he also worked on the fecundity, growth, ethology and environment of the species and conscientiously followed ABFT catches in the traps of southern Spain from the point of view of their biology and fishing yield (Rodríguez-Roda 1964).

After the great advance on the knowledge of the ABFT carried out during the first half of the 20th century, in recent decades there has been a great deal of scientific production contributing considerably to our knowledge of the biology of ABFT and its population dynamic, precisely at a time in which the species has shown signs of fishing overexploitation, mainly in the last decades (ICCAT 2008). Below some publications are cited, listed by their general subject matters:

Reproduction and fecundity: Rodríguez-Roda (1967), Baglin (1982), Medina et al. (2002), Karakulak et al. (2004), Corriero et al. (2005), García et al. (2005), Heinish et al. (2014), Addis et al. (2016), Richardson et al. (2016).

Larvae and larval ecology: Piccinetti and Piccinetti Manfrin (1970), Dicenta and Piccinetti (1980), García et al. (2006), Alemany et al. (2010), Álvarez-Berastegui et al. (2014), Reglero et al. (2012), Laiz-Carrión et al. (2015).

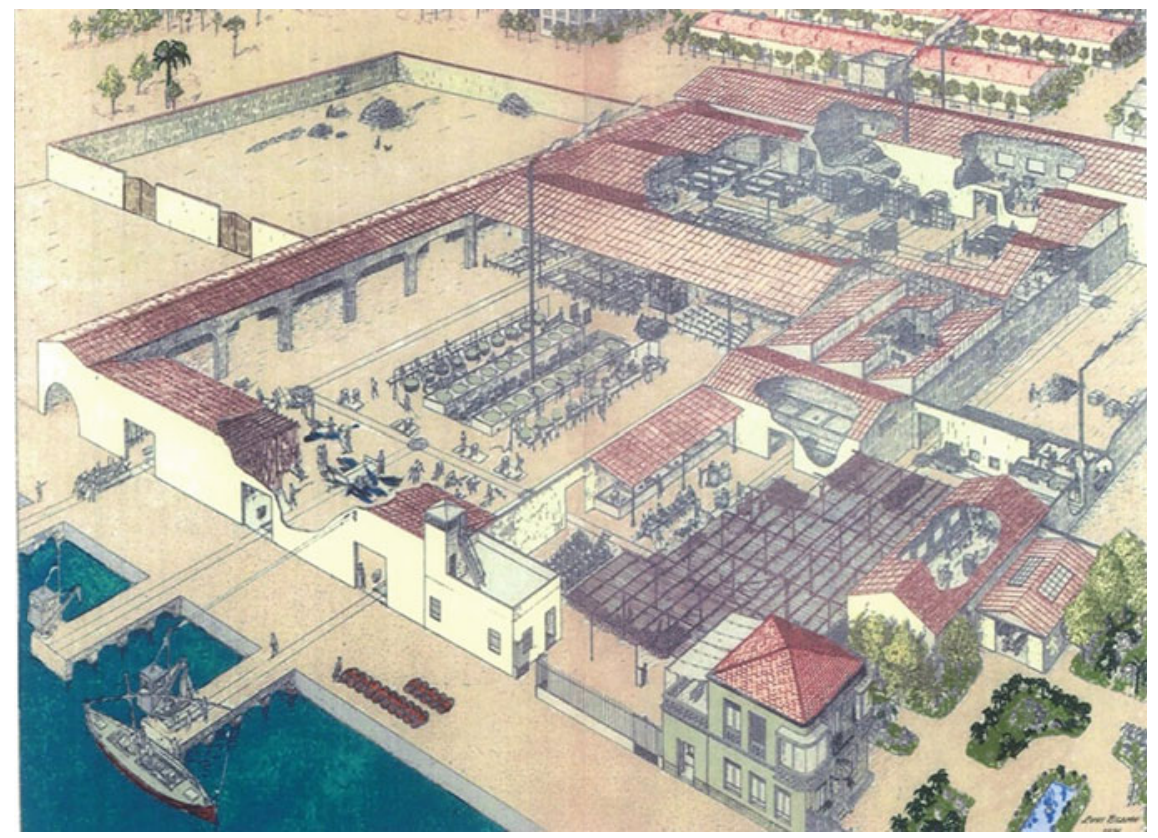

Fig. 5.5 Old tuna canning factory, around 1925 (Adapted from Bellón, 1926) 


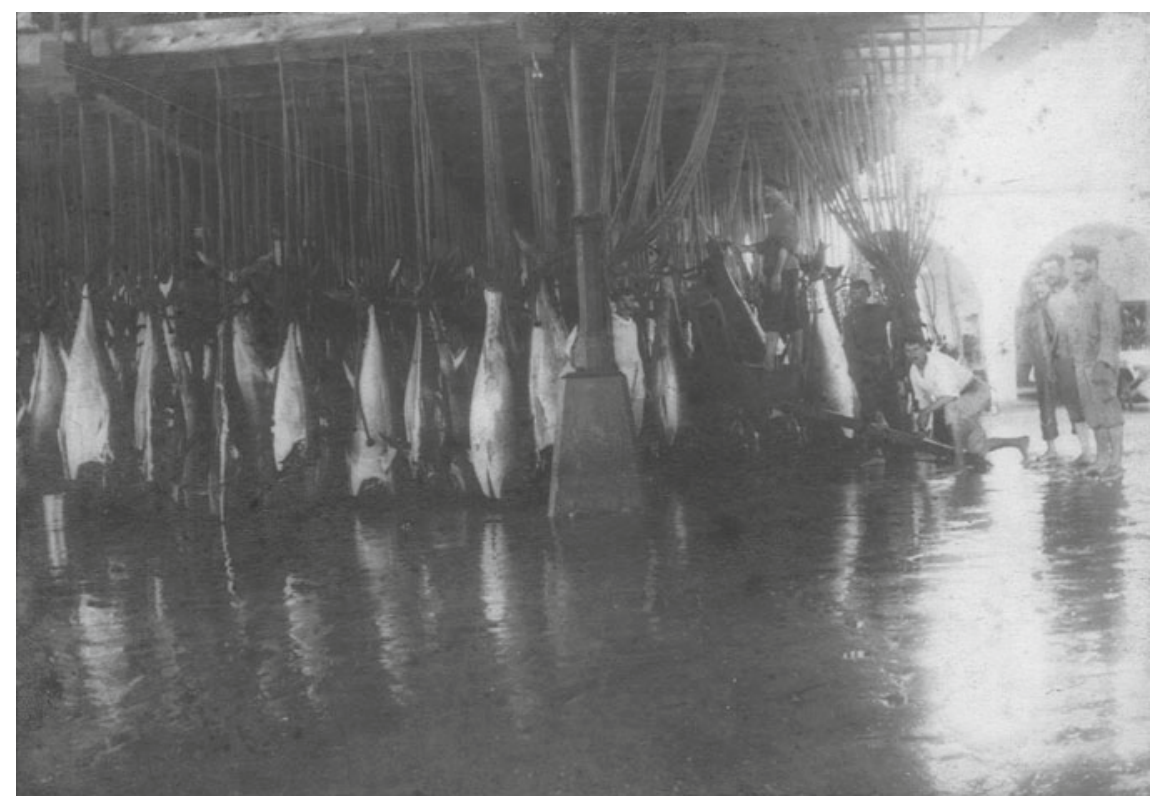

Fig. 5.6 "The tuna forest" in a canning factory of tuna caught by the traps, around 1925 (Documentary archive, IEO)

Feeding: Estrada et al. (2005), Sarà and Sarà (2007), Logan et al. (2010), Butler et al. (2015), Battaglia et al. (2013), Sorell et al. (2017).

Ecology: Druon et al. (2011, 2016).

Natal origin: Rooker et al. (2014), Fraile et al. (2014), Brophy et al. (2015).

Genetics: Puncher et al. $(2015,2018)$.

Age and growth: Rodríguez-Roda (1964), Caddy et al. (1976), Butler et al. (1977), Compeán-Jiménez and Bard (1983), Cort (1990), Santamaria et al. (2003), Rodríguez-Marín et al. (2007), Restrepo et al. (2010), Cort et al. (2013, 2014, 2015), Luque et al. (2014), Ailloud et al. (2017).

Electronic tagging2: De Metrio et al. (2002), Block et al. (2005), Goñi et al. (2010), Wilson and Block (2009), Medina et al. (2011), Aranda et al. (2013), Lutcavage et al.

\footnotetext{
${ }^{2}$ The internal electronic tags (archival tags) are small computers that are placed in the peritoneal cavity of the ABFT, which record dates, times, fish depths, water temperature, body temperature and light levels, which are used to calculate an approximate daily position of the tagged animal depending on the times of dawn and dusk and the angle of the sun. To download the data the fish must be recovered. The electronic tags can record data every few seconds over several years depending on the tag's sampling frequency and the duration of the battery.

The electronic pop-up tags, also known as PAT satellite tags, compile information on oceanic movements and preferred water temperature, clarity and currents through GPS location technology. They are pre-configured to come loose at a programmed time and rise to the surface to transmit the
} 
Fig. 5.7 Bluefin tuna of 530 $\mathrm{kg}$ caught in the trap of Barbate (Spain). Strait of Gibraltar, 6/24/1954 Photo: F. Lozano (1958)

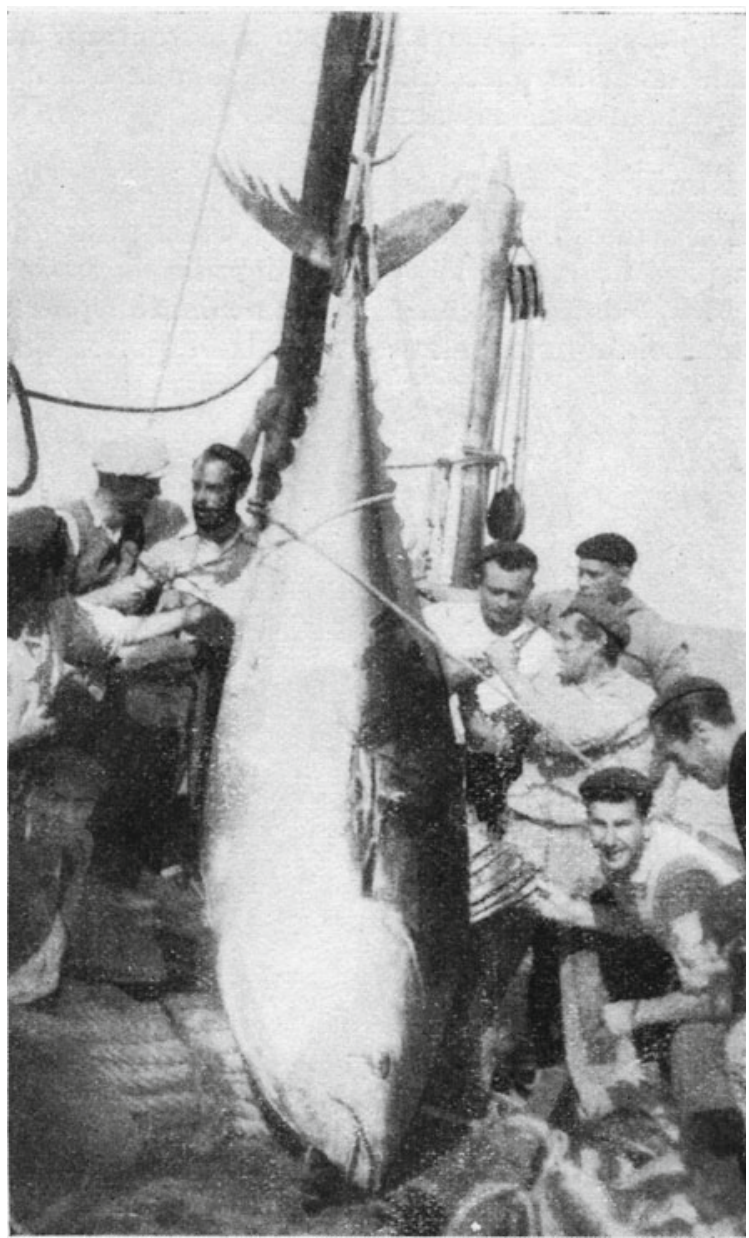

(2013), Quílez-Badia et al. (2013), Cermeño et al. (2015), Galuardi et al. (2015), Abascal et al. (2016), Di Natale et al. (2016), Tensek et al. (2018).

Aerial and acoustic prospection: Lutcavage et al. (1995, 1997), Vanderlaan et al. (2014), Melvin (2016), Goñi et al. (2017), Rouyer et al. (2018).

Natural mortality: Brodziak et al. (2011), Fonteneau and Maguire (2014).

Stock assessment: Anonymous (1994), Fromentin et al. (2014), ICCAT (2017).

In several published synopses (Mather III et al. 1973, 1995; Fromentin and Powers 2005; Rooker et al. 2007; ICCAT 2010) and numerous studies carried out in the

data to the Argos satellite network. This network collects, processes and disseminates environmental data and has a special channel dedicated to wildlife telemetry. 


\section{Biología del Atún, Thunnus thynnus (L.), de la costa sudatlántica de España \\ por \\ JULIO RODRIGUEZ-RODA}

\section{INVESTIGACION PESQUERA}

Tomo XXV.-Publicado en enero de 1964

BA RCELONA

1964

Fig. 5.8 Cover of the article by Rodríguez-Roda (1964) 


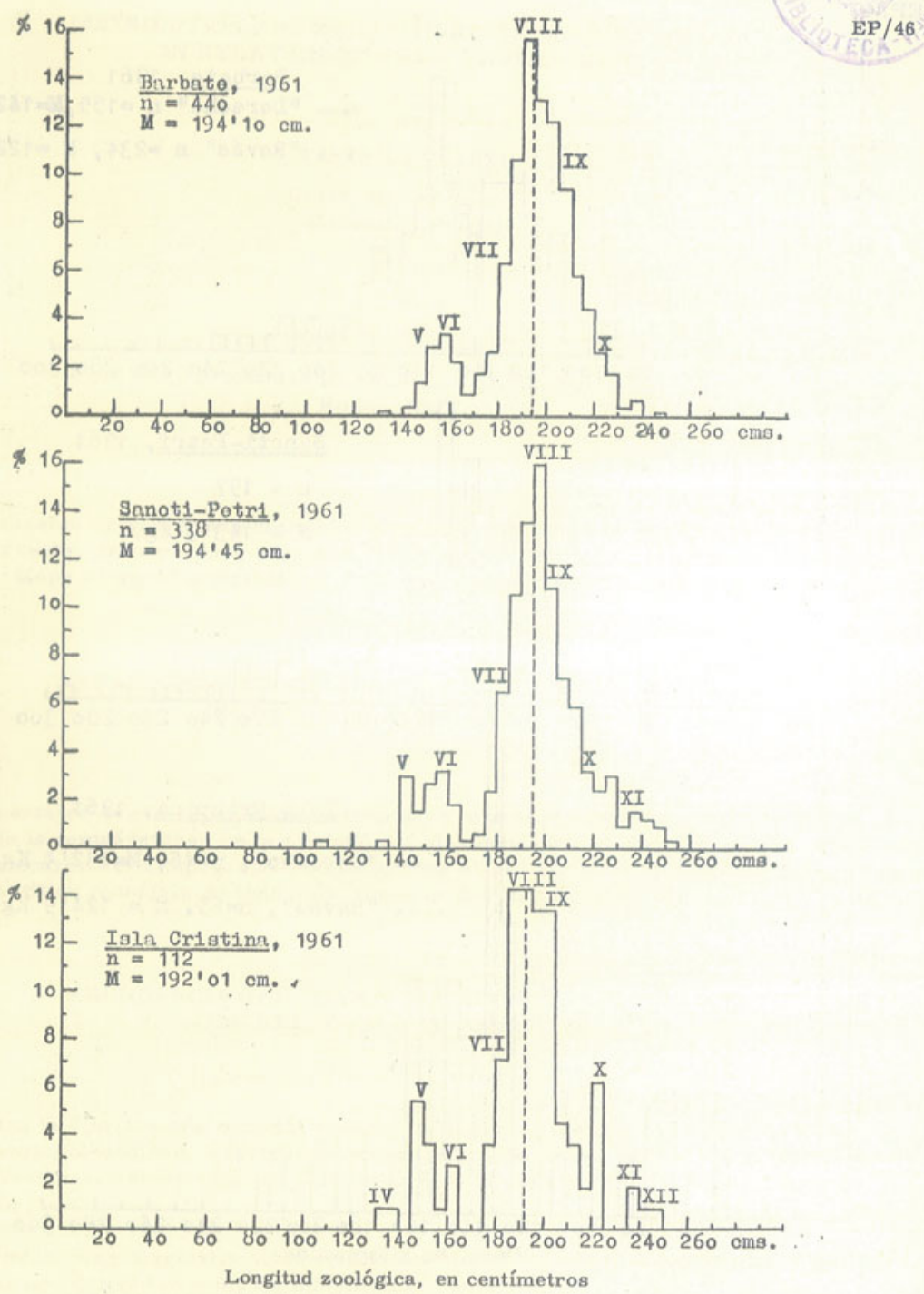

Fig. 2. Frecuencias de tallas del atún, Thunnus thynnus

Fig. 5.9 Length distribution of bluefin tuna caught by the traps, expressing the ages of the different groups in Roman numbers, according to Rodríguez-Roda (1962) 
field of ICCAT-GBYP Research, many more bibliographic references and published articles on the subjects cited and other can be found.

\subsection{Chronology and Description of Two Symposiums and the ICCAT-GBYP Project}

Soon after the implementation of PARP (2008) and when there were still no signs of the recovery of the eastern ABFT stock, the SCRS organized two symposiums that are going to be analysed since they are related to the traps fisheries.

One of the facts of the current age, which has previously been described, is related to the dramatic fall of the catches of the traps in the Strait of Gibraltar (Fig. 5.10) at the beginning of the 1960s as well as the collapse of the North Sea fisheries; this is the case of the Norwegian purse seine fishery (Fig. 5.11) and several commercial (Tiews 1978) and recreational fisheries of the time (Fonteneau and Le Person 2009; Ross 2010).

Several theories have been put forward regarding these events attempting to explain what happened to the ABFT spawning population from those years onwards in the eastern Atlantic, and what made the spawner fisheries disappear within just a few years. Several publications have pointed to environmental factors, the scarcity of ABFT preys in trophic areas and changes in the migratory behaviour of this species

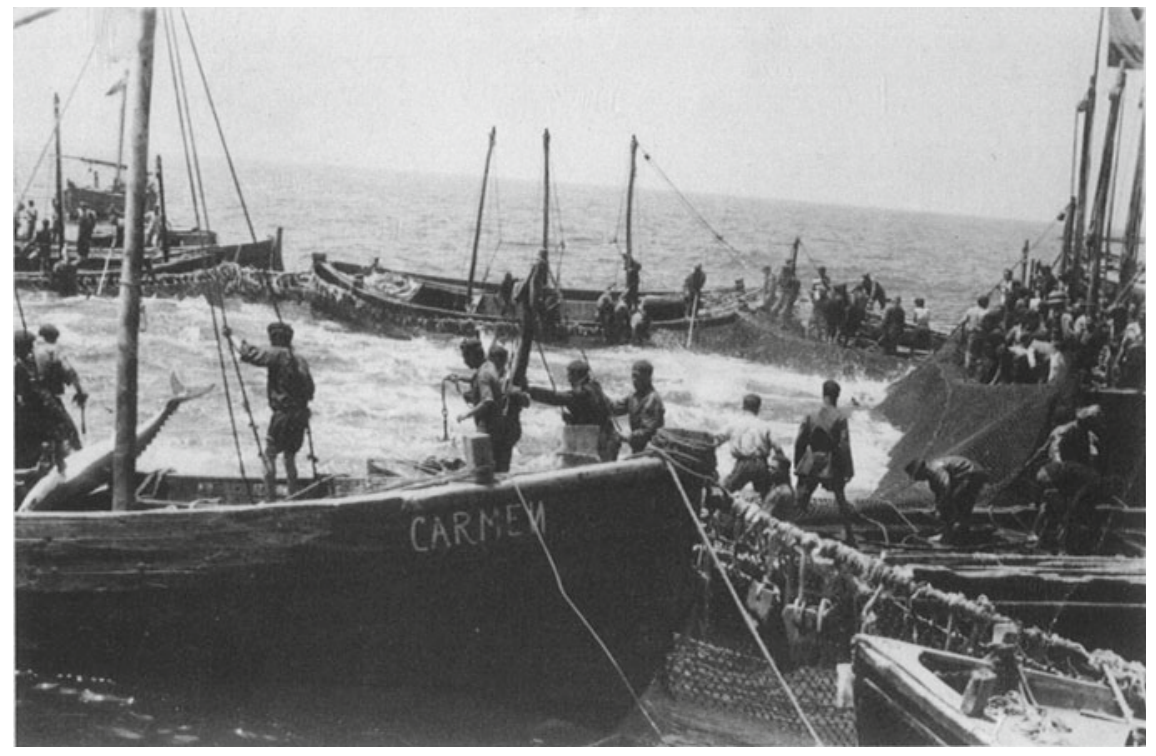

Fig. 5.10 Trap of Sancti-Petri (Spain), 1949 (Documentary archive, IEO) 


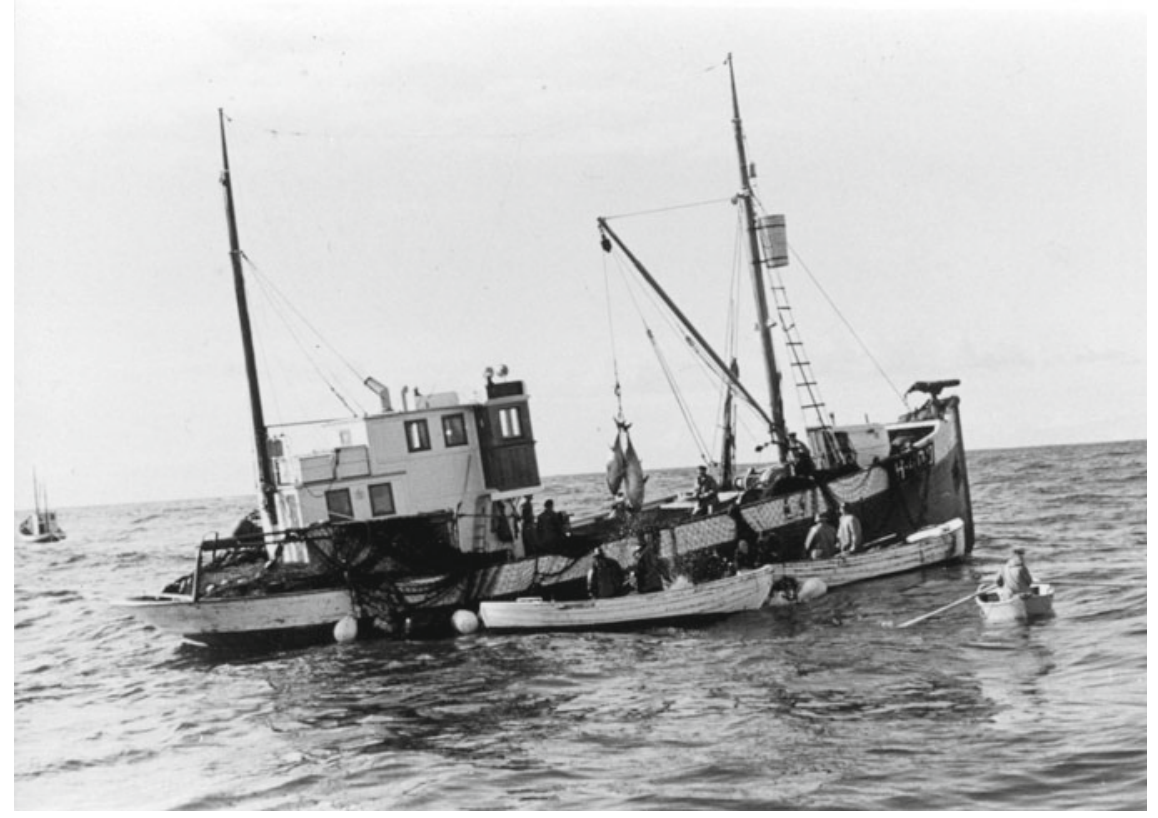

Fig. 5.11 Norwegian purse seiner (1957) (Courtesy of IMR, Norway)

as the main reasons (Tiews 1978; Fromentin 2002, 2009; Fromentin and Powers 2005; Ravier and Fromentin 2001, 2004; Fromentin and Restrepo 2009).

With the aim of resolving the mystery of the decline in the spawning stock, which sustained the traps fisheries and those of the north of Europe until the 1960s, Cort and Nøttestad (2007) proposed at the SCRS meeting in 2006 that a symposium be held to debate the issue. The proposal was recommended by the scientific committee and later accepted by ICCAT (2007). It took a year to organize and find sponsors, and the event was finally held in Santander (Spain) in April 2008 (Fig. 5.12). The Symposium also considered the Pacific bluefin tuna, Thunnus orientalis ( $\mathrm{T}$ and $\mathrm{S}$ ) fisheries, a species that has found itself in a similar situation to ABFT for decades. Similarly, an overall vision of the southern bluefin tuna (Thunnus maccoyii, C.) fishery was presented.

\subsubsection{World Symposium on Bluefin Tuna in Santander (2008)}

The following is a literal transcription of some of the content of the report in ICCAT (2009). 


\subsubsection{Background}

The aim of the Symposium was to provide a deeper investigation of events that took place decades ago and to improve the understanding of these intriguing past events. This information should further help in improving current management and conservation measures for bluefin tuna fisheries.

The Symposium was a response to a recommendation of the Standing Committee on Research and Statistics (SCRS) in 2006.

Previous studies carried out within the framework of ICCAT have stressed the disappearance of some past fisheries or the drastic fall in the yields of others that generate changes in the spatial distribution of the catches.

\section{PESCA \\ Expertos analizarán en Santander la «delicada» situación del atún rojo}

En el marco de este evento se abordará la evolución histórica y las causas de la desaparición de algunas pesquerías históricas de esta especie

\begin{tabular}{l} 
ALERTA / SANTANDER \\
\hline Un centenar de científicos y exper- \\
tos procedentes de todo el mundo \\
participarán en el Simposio Mun- \\
dial para el Estudio de la Fluctua- \\
ción de los Stocks de Atún Rojo que \\
se celebrará del 22 al 24 de abril \\
en Santander. En el marco de este \\
evento se analizará la evolución his- \\
tórica y las causas de la desapari- \\
ción de algunas pesquerías histó- \\
ricas de esta especie que atraviesa \\
una situación edelicada y upeligro- \\
san y se enfrenta a un futuro «muy \\
inciertow. El objetivo del Simposio, \\
organizado por Instituto Español \\
de Oceanografia (IEO), junto con \\
la Comisión Internacional para la \\
Conservación del Atún Atlántico \\
y en colaboración con la Sociedad \\
Regional Cantabria I+D+i (Idican), \\
el Ministerio de Educación y Cien- \\
cia y el Ayuntamiento de Santan- \\
der, es extraer conclusiones sobre \\
la caída de pesquerias y proponer \\
actuaciones para proteger la especie \\
y mejorar su situación. Las proposi- \\
ciones se trasladarán a la Comisión \\
Internacional para la conservación \\
del atún rojo. La jornada, que se \\
desarrollará en siete sesiones te- \\
máticas relacionadas, todas ellas, \\
con la situación presentey futura de \\
estos túnidos, fue presentada ayer, \\
jueves 17 , en rueda de prensa por \\
el delegado del Gobierno en Can- \\
tabria, Agustín Ibáńez, el director \\
general de Pesca del Gobierno re- \\
gional, Fernando Torrontegui, y el \\
director del Instituto Oceanográ- \\
fico de Santander, José Luis Cort. \\
Entre las causas de la desaparición \\
del atún rojo en pesquerias históri-
\end{tabular}

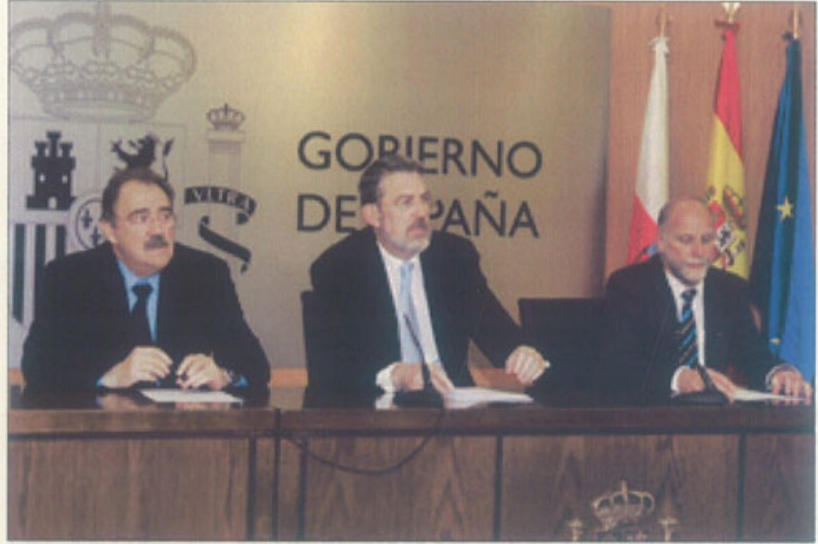

Aqustín Ibáñez, Fernando Torrontequi y José Luis Cort en la presentación de la jornada. /oceth

La cuota no llega a 1.200 toneladas para los barcos españoles

Durante la presentación del Simposio Mundial, Torrontegui señalo que la cuota de pes. quería de atún rojo reservada en 2008 para los quería de attin rojo resenada con 2008 para los b3 barcos que faenanen el Cantabrico-19 de toneladas mientras que en el conjunto estatal asciende a 5.378 toneladas. La cuota total para

cas, Cort destacó la sobreexplota- efectos ambientales derivados del la contaminación, que fue euno de ción de la especie. Un fenómeno al cambio climático que han repercu- los argumentos principales» de la que hay que sumar, según dijo, los tido en países del norte de Europay desaparición.

Fig. 5.12 Press conference on the de bluefin tuna symposium in the Spanish Government Delegation in Santander Diario Montañés, Santander (4/18/2008) 
Although these events occurred in past decades, they have marked the future of the fisheries. In the Atlantic, these events occurred in the 1960s, whereas in the Pacific, during the late 1800s and early 1900s, several fisheries that occurred in northern Japan suddenly disappeared, while more recently, several new fisheries have started in the Sea of Japan and coastal areas of northern Japan.

The Symposium was jointly organized by ICCAT and the Instituto Español de Oceanografía (Spanish Institute of Oceanography), IEO.

The IEO and ICCAT jointly organized the "World Symposium for the study of fluctuations in northern bluefin tuna (Thunnus thynnus and Thunnus orientalis), including historical periods". At the event, which was held in Santander (Spain) between 22nd and 24th April 2008, 85 scientists from all over the world took part.

In 2007, the president of the SCRS, named a permanent committee made up of doctors J. M. Fromentin (France), J. Powers (U.S.A.) and N. Miyabe (Japan); this committee was coordinated by J. L. Cort (Spain).

The Symposium opened on April 22, 2008 with an official opening ceremony presided by Dr. Fabio Hazin, ICCAT Chair. Dr. Hazin thanked the Government of Cantabria and the city of Santander for hosting the meeting.

The ICCAT Chair emphasized the opportunity the Symposium presented at a time when the stock of North Atlantic bluefin tuna, particularly in the eastern Atlantic and Mediterranean Sea, was facing one of its worst crises in the history of the fishery. Dr. Hazin expressed the wish that the Symposium would help the SCRS to better assess the bluefin tuna stock and therefore contribute towards improving the management of the stocks.

Other scientific authorities of national and local administrations, as well as the municipal authority, spoke before the debate was opened.

The Symposium was organized in seven topical sessions coordinated by a moderator.

The present study only considers the sessions dedicated to Thunnus thynnus.

The documents of the symposium are available at ICCAT (2009).

\subsubsection{Session 1: Historical Synthesis of the Bluefin Tuna Fisheries}

SCRS/20108/058. Fonteneau, A. Atlantic bluefin tuna: An overview of 100 centuries of moving fisheries.

SCRS/2008/059. Fonteneau, A. and A. Le Person. Bluefin fishing in Lannion Bay, northern Brittany, during the 1946-1953 period.

Moderador: G. Scott (NOAA, U.S.A.)

Speaker: A. Fonteneau (IRD, France)

- Bluefin tuna fisheries have been identified in different areas of the Atlantic and Mediterranean over the last 10,000 years. Since the beginning of the XXth century these fisheries have undergone considerable industrial development.

- The historical analysis confirms large-scale migrations and shows that bluefin tuna has been caught in a wide range of ecosystems between 2 and $29^{\circ} \mathrm{C}$, many changes 
being observed in where and when the species is caught. This fact is difficult to explain, although it would appear to be a combination of environmental and fisheries factors; exploring these more deeply will contribute to an improvement in the quality of assessments on the state of the stocks.

- A practical example to orientate future studies regarding the previously mentioned spatial-temporal changes concerns the recreational fisheries of Northern Europe in the middle of the XXth century; such is the case of the fishery in Trebeurden Bay (British Channel), practiced between 1946 and 1953. This small fishery, associated with the presence of sardines in the area, provided a great deal of useful biological information related to the North Sea and Norwegian coastal bluefin tuna fisheries.

The Symposium noted it is apparent that there are a number of important fishery dynamics that haveoccurred which have not been taken directly into account in our recent assessments of bluefin stock status in the ICCAT Convention area and concluded from Session 1 that:

- Our assessments of Atlantic bluefin stock status mainly focus on recent history, for which more detailed information is available about the catch, effort and size composition of the catch.

- These assessments are uncertain, especially so regarding biomass levels that are necessary to meet the requirements of the ICCAT Convention.

- Incorporation of more historical information could better inform us of stock productivity and abundance levels consistent with the ICCAT Convention objectives.

- Our challenge will be to apply methods for stock status assessments that are more appropriate to the added complexities of the history we can piece together.

\subsubsection{Session 2: The collapse of the North Sea and Norwegian Coastal Bluefin Tuna Fisheries}

SCRS/2008/060. Tangen, $M$. The Norwegian fishery for Atlantic bluefin tuna. SCRS/2008/061. Nøttestad, L., Ø. Tangen and S. Sundby. Norwegian fisheries since the early 1960s: What went wrong and what can we do?

SCRS/2008/062. MacKenzie, B. R. and R. A. Myers. The development of the northern European fishery for North Atlantic bluefin tuna, Thunnus thynnus, during 1900-1950.

Moderator: B. McKenzie (INRA, Denmark)

Speaker: L. Nøttestad (IMR, Norway)

- Different descriptions of the ecosystem, before, during and after the disappearance of bluefin tuna from these fisheries, suggest that the collapse was not caused by great changes in water temperature, since bluefin tuna was present in times of high temperatures until 1960, and was also later caught in places where the temperature was as low as $3{ }^{\circ} \mathrm{C}$.

- The coincidence of the collapse of herring stocks in the North Sea in the 1960s may explain the disappearance of medium-sized spawning bluefin tuna $(<2 \mathrm{~m})$ from 
these traditional fishing areas in the same years; large adults $(>2 \mathrm{~m})$ were still present even with a scarcity of herrings for a few more years until their complete disappearance at the beginning of the 1980s.

The following causes are suggested that may have led to the absence of bluefin tuna in these fisheries:

- Changes in migratory behavior,

- Scarcity of adults in the population, and/or

- The high exploitation of juveniles in other areas (Bay of Biscay, coasts of Portugal and Atlantic fisheries of Morocco).

- On the other hand, the ideal conditions of the ecosystem since the 1990s with a great abundance of bluefin tuna prey including herring, mackerel and even anchovy, and optimal sea temperatures, leads to the conclusion that the fundamental reason behind the bluefin tuna's disappearance and failure to return to these latitudes is the precarious condition of the population in the ocean.

The reasons why these fisheries are difficult to reconstruct are:

- The continual fall in spawning biomass over the last 10-12 years, which at its lowest point since the first records of ICCAT. The quantity of older fishes in the population has fallen,

- The increase in the exploitation of juveniles since 1950. With an exploitation pattern in which $80-90 \%$ of fishes caught are aged 1-3 years $(<30 \mathrm{~kg})$, together with undeclared catches of age 0 fishes $(<2 \mathrm{~kg})$, a large part of the bluefin tunas recruited will never have the chance to reproduce.

The Symposium raised a number of research questions in the discussion of presentations in Session 2:

- The role of learning of migration patterns by young tuna from older tuna, and the necessity for overlap of spatial distributions of young and old tuna; the mechanisms by which learning is accomplished are unclear;

- The possibility to acquire observational and occasional landings data via commercial and sport fishermen targeting other species and via whaling observers in northern European waters;

- Possible links via migration to the population in the West Atlantic;

- Attempts to estimate biomass in the early 1950s from age composition of catches and cohort identification;

- Uncertainty of stock-recruit relationship;

- The potential for individual tuna to skip spawning and subsequently to reduce fidelity to former spawning sites; and

- The role of squid abundance and prey (especially herring) condition on bluefin tuna diets and condition. 


\subsubsection{Session 3: Decline of the Adult Fisheries of the Cantabrian Sea}

SCRS/2008/063. Cort, J. L. The bluefin tuna (Thunnus thynnus) fishery in the Bay of Biscay.

SCRS/2008/064. Cort, J. L. and E. Rodríguez-Marín. The bluefin tuna (Thunnus thynnus) fishery in the Bay of Biscay. Evolution of 5+ group since 1970.

SCRS/2008/065. Cort, J. L., P. Abaunza and G. De Metrio. Analysis of the northeast Atlantic juvenile bluefin tuna (Thunnus thynnus) population between 1949 and 1960. SCRS/2008/066. Rodríguez-Marín, E., J. M. Ortíz de Urbina, E. Alot, J. L. Cort, J. M. de la Serna, D. Macias, C. Rodríguez-Cabello, M. Ruiz and X. Valeiras. Following bluefin tuna cohorts from east Atlantic Spanish fisheries since the1980s.

Moderator: E. Rodríguez-Marín (IEO, Spain)

Speaker: J. L. Cort (IEO, Spain)

- The fishery is traditionally made up of juveniles (1-4 years; between 4 and $35 \mathrm{~kg}$ ). In the past there was a constant presence of medium-sized adults (up to $2 \mathrm{~m}$ ) in the Bay of Biscay on the trophic migration from the spawning areas of the Mediterranean to feeding grounds in the North Sea. These groups have now practically disappeared from the fishery.

- A sharp fall in the abundance of fishes aged 5+ (mean weight $62 \mathrm{~kg}$ ) has been observed since the beginning of the 1970s in a fishery dominated by the catch of juveniles for the last three decades: $96.6 \%$ of the catch in number of fishes are juveniles.

- The results of an analysis of the population of the Atlantic juvenile fisheries between 1949 and 1960 show that under different scenarios the high fishing mortality exerted during the years studied may have contributed to the fall in the spawning population of the eastern Atlantic and as a result been one of the causes of the decline in the fisheries of the north of Europe and the traps from 1963. The hypotheses that underlie the analysis show the existence of a certain degree of independence ("resident populations") of eastern and western Mediterranean juvenile bluefin tunas based on recent studies using electronic pop-up tags.

The Symposium raised a number of research questions in the discussion of the presentations in Session 3:

- To what degree did the development of fishing on the juvenile component of the stock from the 1950s to the 1970s influence the success of the catch of adults in the traps, in northern European waters, and the loss of age 5+ fish in the Bay of Biscay fishery?

- The utility of strong annual year classes to establish relationships between fishing grounds?

- It is important to know the contribution of recruits from the Mediterranean to the Atlantic fisheries:

- Is there a wide variation in the proportion of fish leaving the Mediterranean? 
- Does this proportion have any relationship with density-dependent effects (competition for space and for food)?

- As recovery rates in the Mediterranean are lower than in the east Atlantic, could this result in overestimating the number of Atlantic bluefin tuna leaving the Mediterranean?

- What are the general trends in distribution and movements of the juvenile component that leaves the Mediterranean?

- How important are learned behaviours and does the extirpation of abundances from other fishing grounds have strong implications in maintaining the presence of fish for the Bay of Biscay fisheries?

\subsubsection{Session 4: Overall Vision of the Eastern Atlantic and Mediterranean Fisheries, Particularly the Traps}

SCRS/2008/067. Fromentin, J. M. Back to the future: investigating historical data of bluefin tuna fisheries.

SCRS/2008/068. Abid, N. and M. Idrissi. Analysis of the Moroccan trap fishery targeting bluefin tuna (Thunnus thynnus) during the period 1986-2006.

SCRS/2008/069. Bridges, C. R., O. Krohn, M. Deflorio and G. De Metrio. Possible SST and NAO influences on the eastern bluefin tuna stock-the inexfish approach. SCRS/2008/070. Karakulak, F. S. and I. K. Oray. Remarks on the fluctuations of bluefin tuna catches in Turkish waters.

SCRS/2008/071. Vella, A. Bluefin tuna (Thunnus thynnus) fisheries of the Maltese Islands in the central and southern Mediterranean Sea.

SCRS/2008/072. Addis, P., I. Locci and A. Cau. Anthropogenic impacts on the bluefin tuna (Thunnus thynnus) trap fishery of Sardinia (western Mediterranean).

\section{Moderator-Speaker: J. M. Fromentin (IFREMER, France)}

- In 1963 the leading bluefin tuna fisheries, which took place in the Norwegian Sea and North Sea, suddenly collapsed without any warning. While little is known of the reasons underlying this collapse, several hypotheses can be put forward, e.g. changes in bluefin tuna migratory routes, recruitment failure or eradication of a sub-population (all three hypotheses may be due to natural causes and/or overfishing).

- Current overexploitation in the Mediterranean Sea could explain why bluefin tuna did not return massively to the northeast Atlantic since the 1990s.

- An analysis of the Moroccan tuna trap fishery targeting bluefin tuna, which shows that the CPUE generally decreased from 1986 to 1995 , increased during the period 1996 to 2001, and has since shown a downward trend.

- Historical data sets on catch and also model-generated data on spawning stock biomass (SSB) and recruitment have been used to look for possible influences of the North Atlantic oscillation (NAO) on the eastern bluefin tuna stock. Initial evidence has shown that total catch can be correlated to the winter NAO but only after a lag of two years. 
- Turkish trap fisheries for bluefin date back to the 15 th century. Fish traps used to be set in the Sea of Marmara, Bosphorus and in the Black Sea from April/May to late August. With the fall in fish stocks, marine pollution and urbanization, fish traps lost their importance in the Turkish bluefin tuna fishery. Recent studies show that bluefin tunas have not been migrating to and from the Black Sea since 1986.

- Traps in the Maltese Islands have caught bluefin tuna since 1748, reaching stable usage around 1948. However, this fishing method was finally replaced by longline.

- The traditional traps of Sardinia harvest the ancestral migratory flow of the Atlantic bluefin tuna at a fixed site. Therefore, it is reasonable to consider local perturbations generated by social and economic events and environmental changes as disruptive to the pathways of bluefin tuna schools and thus account for variability in the Mediterranean trap captures.

The Symposium concluded from Session 4:

- There was a strong connection between the Nordic fisheries and the northeast Atlantic traps (from Spain, Portugal and Morocco) and secondarily with Mediterranean traps as well as the northwest Atlantic trap. The collapse of the Nordic fisheries is not an isolated event.

- Atlantic bluefin tuna might be seen as a metapopulation made up of at least by three sub-populations that have varied in size in response to environmental changes and overfishing. Individual markers may be of great help to test the metapopulation hypothesis and thus the stock structure of bluefin tuna, as first results tend to show.

- Fishing grounds also changed significantly in the eastern Mediterranean Sea during the 20th century, moving from the Marmara Sea to the Black Sea and finally to the Aegean. In general, there were several extinctions/discoveries of important fishing grounds in the Mediterranean as well as in the east Atlantic during the 20th century.

- The importance of investigating fisheries on different spatial scales: i.e. large scales to detect connectivities between fisheries/stocks and impact of large-scale events (e.g. fishing, climate) and small-scale events to detect the impact of local events (e.g. coastal pollution due to industrial activities).

- Traps provide highly valuable scientific information from an ecological and a fisheries perspective as they are a passive fishing gear being set at the same location and submitted to low technical modifications.

- The causes of drastic changes in the fisheries of the 20th century are likely to result from interactions between biological, environmental, trophic and fishing processes.

\subsubsection{Session 5: Overall Vision of the Western Atlantic Fisheries}

SCRS/2008/073. Takeuchi, Y., K. Oshima and Z. Suzuki. Inference on the nature of Atlantic bluefin tuna off Brazil caught by the Japanese longline fishery around the early 1960s. 
Moderator: J. Neilson (SABS, Canada)

Speaker: M. Lutcavage (UNH, U.S.A.)

- The western Atlantic fisheries also had a long historical record and provided some landings information from the late 1800s for the New England fishery.

- There is some evidence of a change in distribution to the northeast in the U.S. fishery. Possible reasons for the change could be related to prey distributions, and there have been observations of decreased condition of western bluefin tuna in the Gulf of Maine and southern Gulf of St. Lawrence.

- Japanese longline fishery which appeared suddenly and virtually disappeared in about 10 years with a substantial catch around the early 1960s. Among several hypotheses that were proposed to explain this event the authors favoured the temporal distribution hypothesis (similar to the concept of metapopulation).

The Session concluded by emphasizing that:

- The western stock is in a low state of abundance, and the spatial distribution may be changing.

- In common with the eastern stock, there are examples of tuna assemblages that have been extirpated. These have included large-scale aggregations, such as the one off Brazil in the 1960s, and smaller ones, such as the one that supported the trophy sport fishery off Nova Scotia (Sharpe Cup, 1930s-1960s).

- PSAT tagging results show diversity of movement patterns; areas where bluefin have been extirpated would be expected to be periodically revisited, raising the potential for recolonization.

- Changes in size structure can provide a warning of imminent fishery collapse.

\subsubsection{General Discussion. Recommendations}

Some important dynamics in Atlantic bluefin fisheries prior to 1970 should be incorporated into our overall analysis and utilized to shape our scientific advice to the Commission.

In the short-term (before the June 2008 stock assessment), it is unlikely that appropriate methodologies for incorporating historical information with different statistical characteristics into our stock assessment can be achieved to the full satisfaction of SCRS. This could only be achieved over a much longer period. While the current workplan for the 2008 bluefin stock assessment partly addresses the need to incorporate more biological realism into our evaluation of stock status, it is not clear that the current level of uncertainty in the assessment will be reduced in the short-run. Even in view of the high uncertainty, available information indicates that under recent conditions Atlantic bluefin tuna appear rapidly headed toward biological bankruptcy: spawning biomass is quickly shrinking and exploitation rates are much higher than the rate of interest nature provides. Our evaluations tell us that catches of bluefin tuna are now at their highest in ICCAT's history; biomass of age 8 and older bluefin tuna is at the lowest level ever estimated and possibly the lowest since 
1950 or before, and that these catches are much too high to permit the Convention objectives to be achieved. More historical information is likely to better inform us as to the biomass levels to which rebuilding must occur to be consistent with the Convention objective and the rate at which rebuilding can occur to meet the Convention objective, but it is less likely to greatly alter our assessment of current exploitation rates. Critical to the issue is seeking an answer to the question: can bluefin tuna abundance levels previously observed off the coast of Brazil, the North Sea and traps be re-established?

In view of the above, it is incumbent upon SCRS to fully describe the information needed to progress in improving the advice we can offer the Commission and how to obtain such information. This is likely to involve coordinated data collection mechanisms which, in general, have not yet been realized through the various national programs underway.

An important aspect of recovering historical information which can better inform our assessment of bluefin is a data mining activity designed to capture and incorporate historical information into the ICCAT database. It is of key importance that SCRS has full access to all historical fishery data collected on bluefin tuna, especially those from the early years of the 20th century. This data mining should, for instance, target the recovery of all the historical data collected (published and unpublished) on the North Sea fisheries (e.g. within the ICES Tuna Working Group on Norwegian, Swedish, German fisheries and from all other potential sources), from the various traps active in the Atlantic and the Mediterranean Sea and the various bluefin fisheries that have been active during the period but not recorded in the ICCAT database. Data mining efforts should also target the recovery of the various sport fisheries that targeted bluefin tunas in the Atlantic and Mediterranean during the 20th century (allowing the identification of the place and dates of positive activities and the CPUE and sizes of fishes caught by each of these sport fisheries).

\subsubsection{Adjournment}

The General Director of the IEO, Dr. Enrique Tortosa, thanked the participants for their attendance and for the excellent work carried out. Dr. Tortosa pointed out the current false paradox between the exploitation of fishing resources and the conservation of the species. He recognized the importance of the conclusions of the Symposium and the SCRS' work to provide scientific advice. He further noted the relevance of the continued work of ICCAT in the adoption of measures for the management and conservation of the resources. The Director General of the IEO expressed the Spanish Government's wish that public policies in general be based on science and that economy and resources be considered jointly.

Dr. José Luis Cort, the General Coordinator of the Symposium, thanked the participants for the exceptional work carried out. He recognized that the Symposium had represented an excellent forum for discussion on subjects that are rarely discussed in other fora and he judged very positively the discussions held and the conclusions reached.

The Symposium was adjourned on April 24, 2008. 


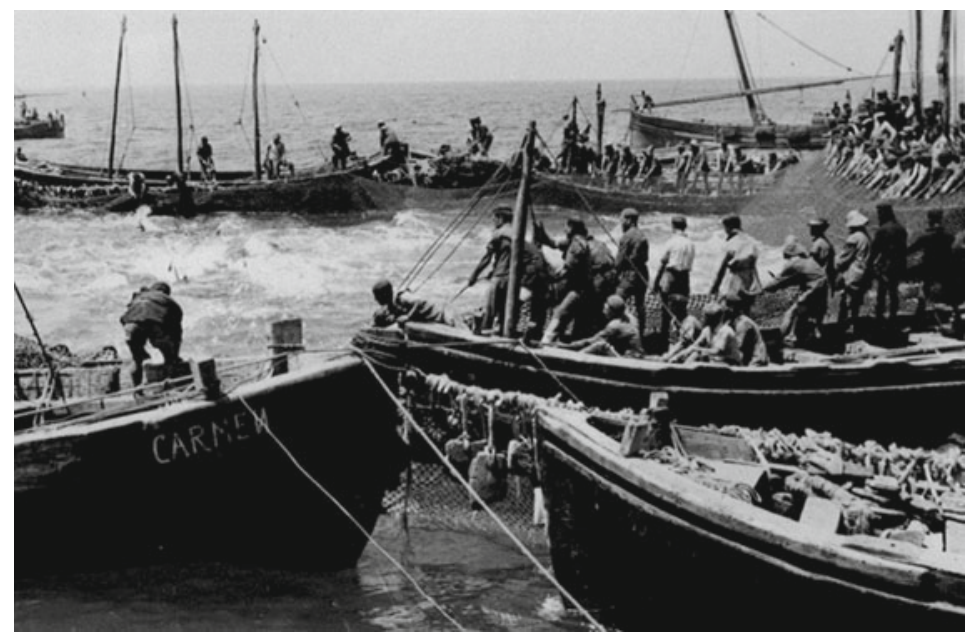

Fishing operations in the trap of Sancti-Petri (Spain), 1949

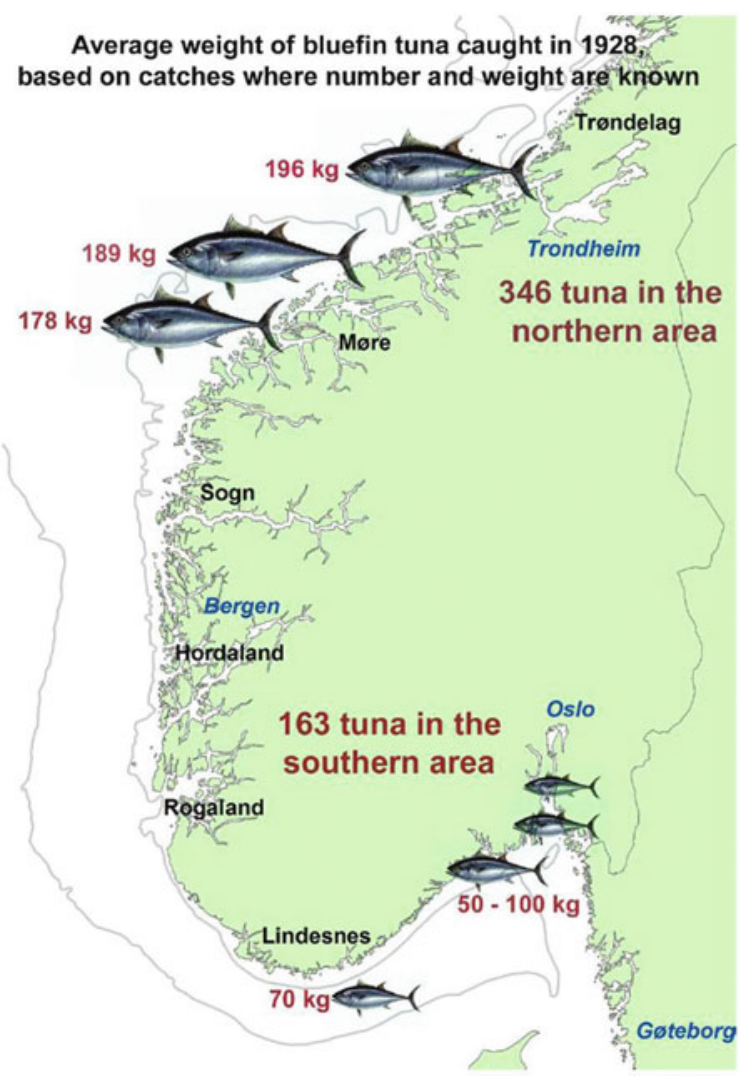

Fishing areas and mean weight of the tunas caught in Norway in 1928 (Courtesy of Øyvind and Magnus Tangen). Taken from ICCAT (2009); Tangen (2009) 


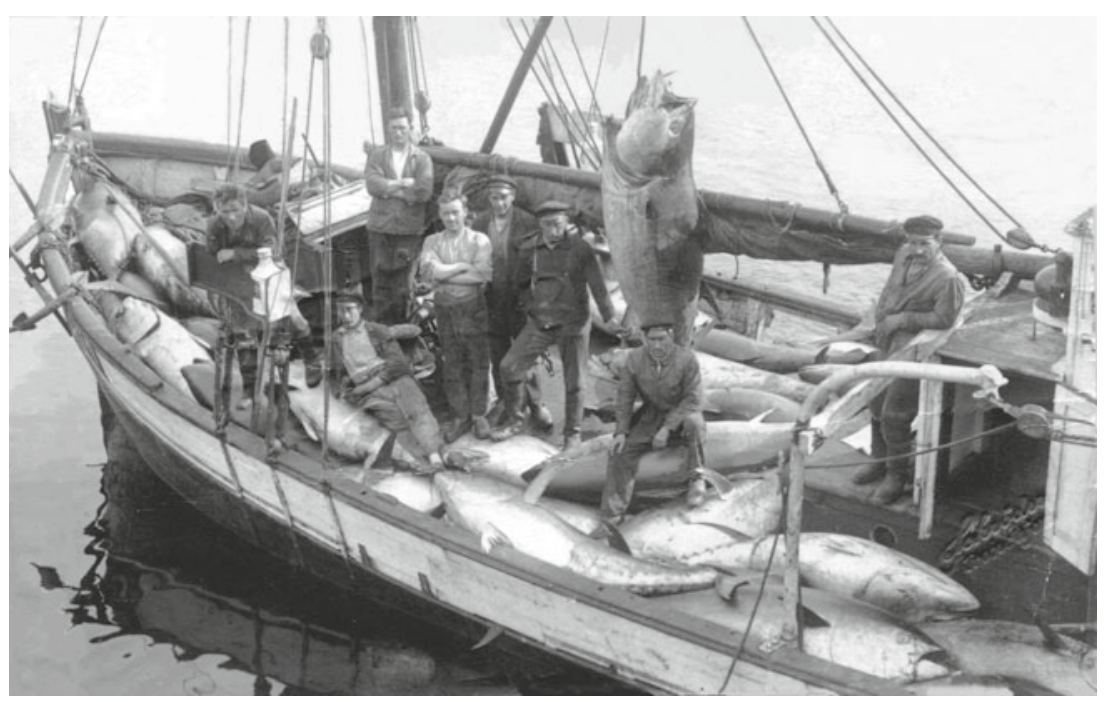

Capture of bluefin tuna with purse seine in Norway (1928). Taken from ICCAT (2009); Tangen (1999, 2009), with the authorization of M. Tangen

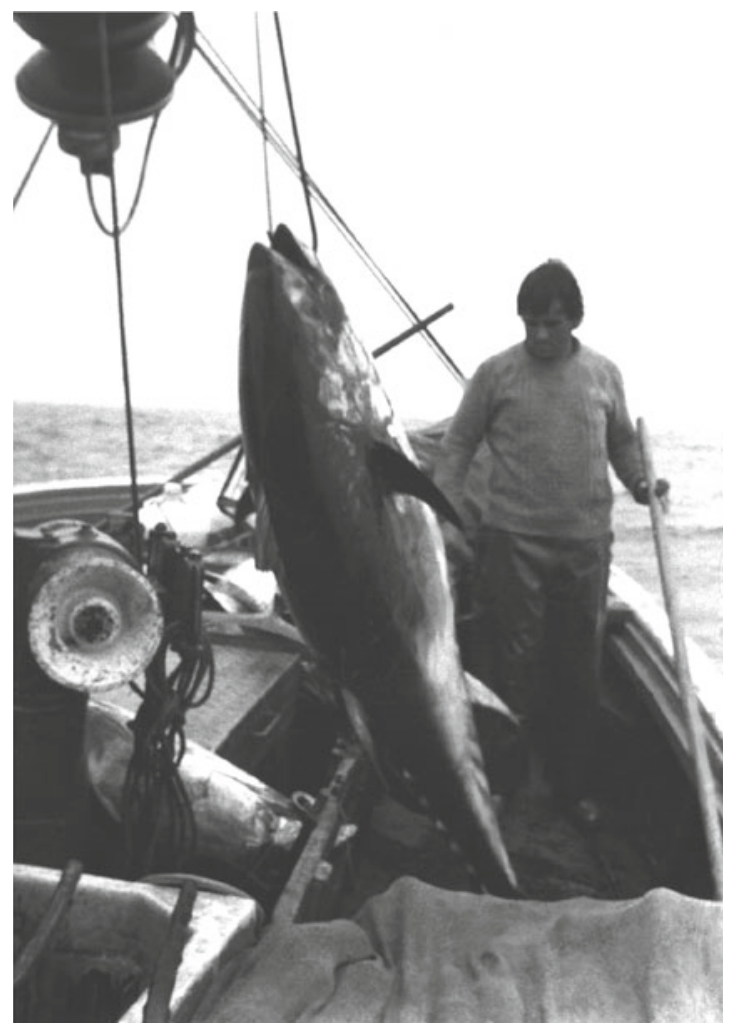

Bluefin tuna fishing in the Bay of Biscay (1973) (http://www.photolib.noaa.gov/bigs/fish2077.jpg) (Documentary archive, IEO) 


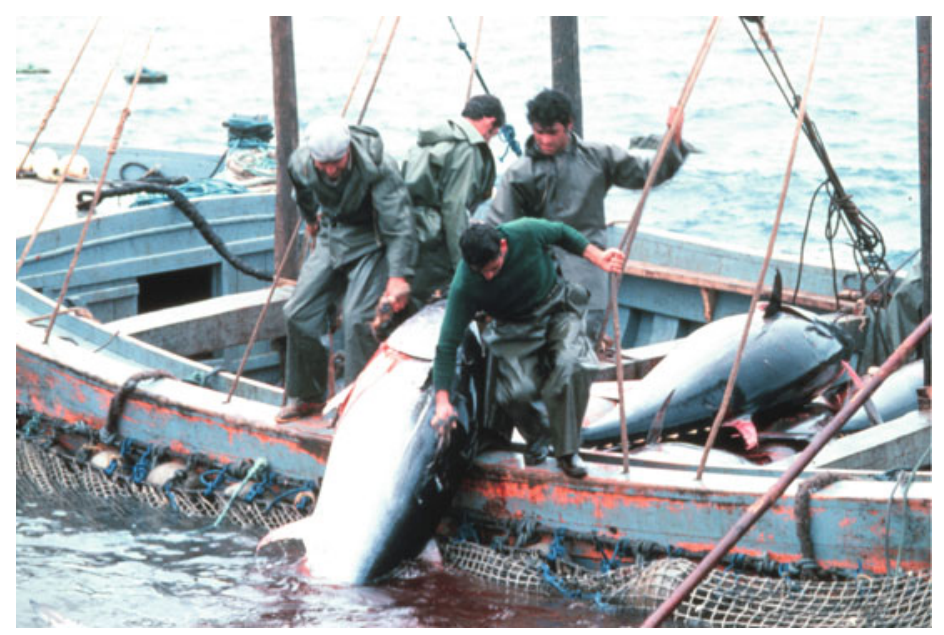

Bluefin tuna fishing in the traps (1982) (http://www.photolib.noaa.gov/bigs/fish2018.jpg) (Documentary archive, IEO)

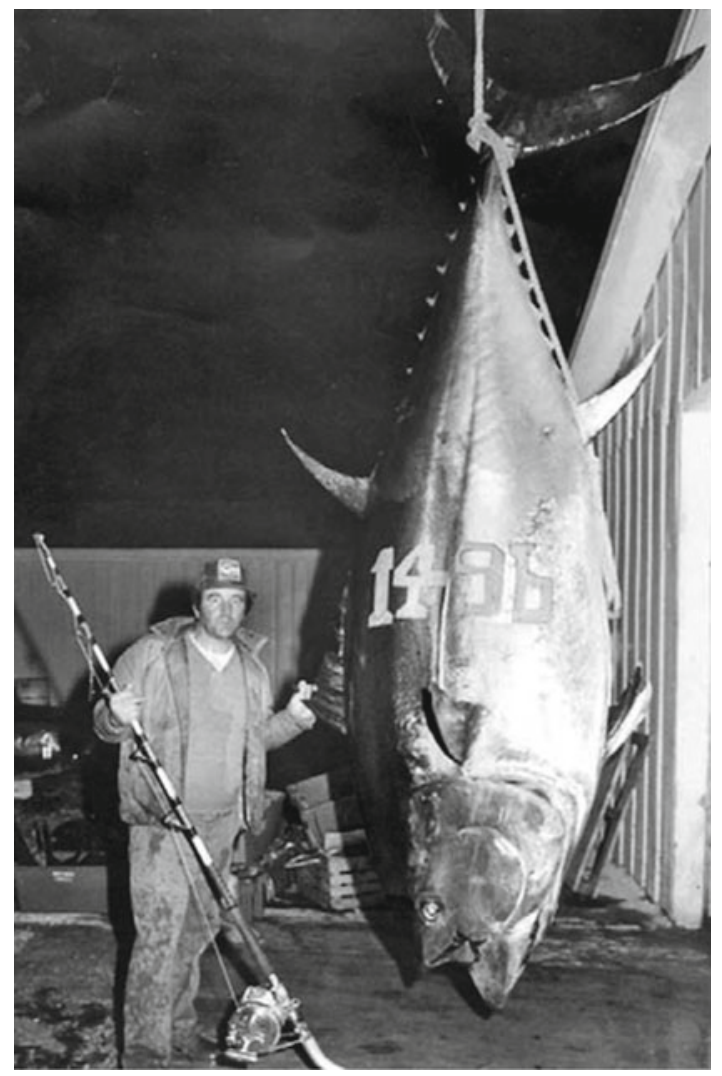

Bluefin tuna, New Stocia (Canada), $1979 W=679 \mathrm{~kg}$, current Guinness world record Fraser (2008) 

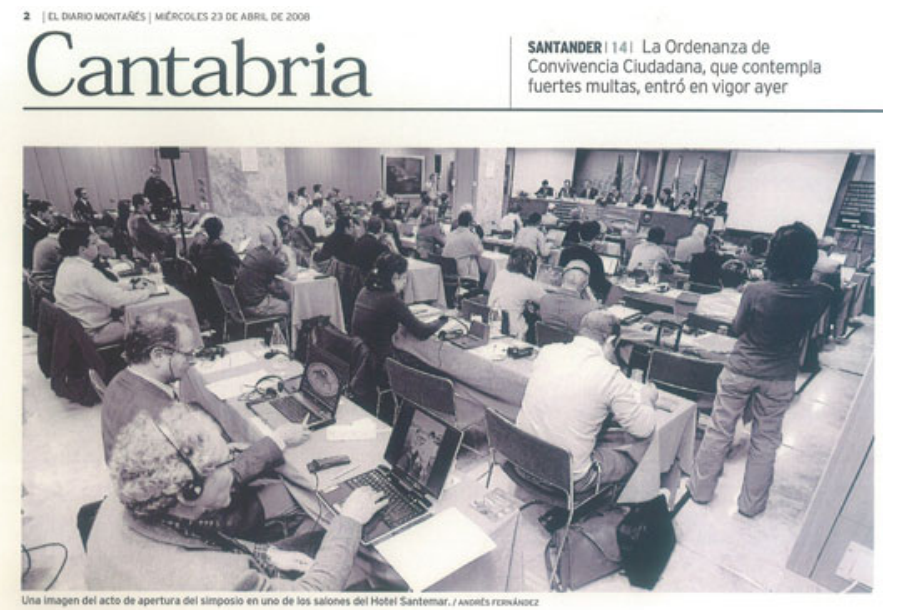

\section{La crisis forzará a restringir más la captura mundial de atunes rojos}

El presidente del ICCAT, Fabio Hazin, se mostró convencido de que la Comisión reducirá las capturas en su próxima reunión de noviembre
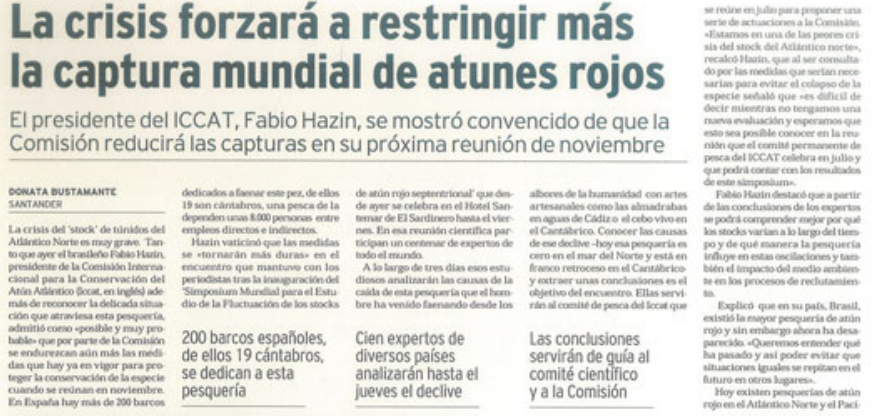

Press note on the bluefin tuna symposium

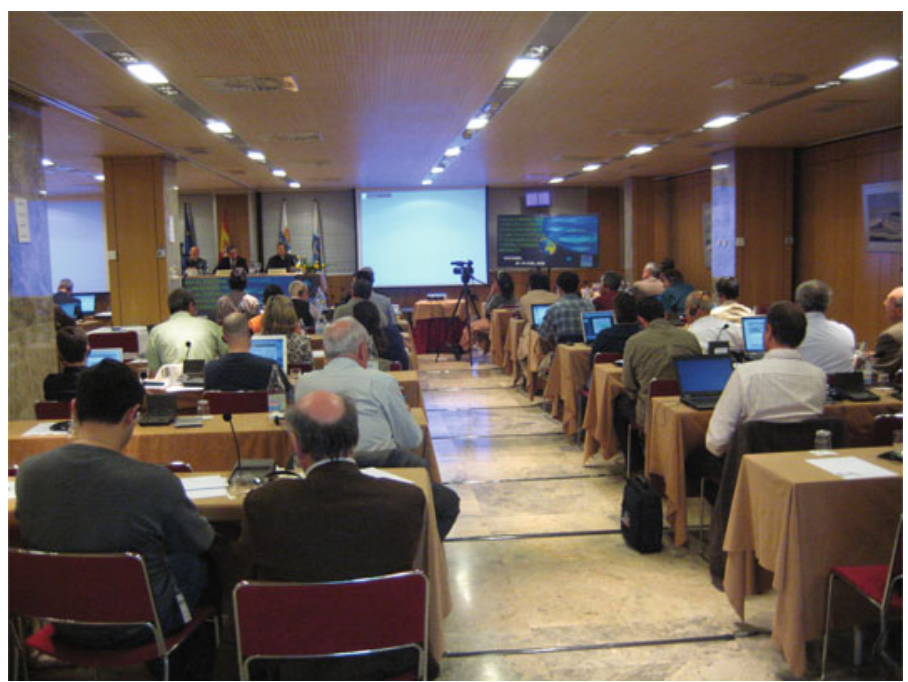

Dr. Enrique Tortosa, Director General of the IEO, during the closing ceremony of the symposium (Documentary archive, IEO) 


\subsubsection{ICCAT-GBYP Project}

According to its website (https://www.iccat.int/GBYP/en/) the project GBYP (Atlantic-wide research programme for bluefin tuna) was officially adopted by the ICCAT Commission in 2008. In 2009 the SCRS identified the priorities of the Research Plan as follows:

1. Improve basic data collection through data mining (including information from traps, observers, and VMS), developing methods to estimate sizes of fish caged, elaborating accurate CPUE indices for Mediterranean purse seine fleets, development of fisheries-independent information surveys and implementing a large scale scientific conventional tagging programme;

2. Improve understanding of key biological and ecological processes through electronic tagging experiments to determine habitat and migration routes, broad scale biological sampling of live fish and dead fish landed (e.g. gonads, liver, otoliths, spines, etc.), histological analyses to determine bluefin tuna reproductive state, biological and genetics analyses to investigate mixing and population structure; and ecological processes, including predator-prey relationships;

3. Improve assessment models and provision of scientific advice on stock status through improved modelling of key biological processes (including growth and stock-recruitment), further developing stock assessment models including mixing among areas, and developing and use of biologically realistic operating models for more rigorous management option testing.

During the Commission Meeting in 2009, a number of Contracting Parties expressed a willingness to make extra-budgetary contributions to such a programme with a view to initiating activities in 2009 related to different priorities: programme coordination, data mining, aerial surveys and tagging design studies; with additional research activities to be undertaken in the following years.

The provision to accept additional contributions from various entities and private institutions or companies was also agreed. In the same document, it was recommended to form a Steering Committee comprised by the SCRS Chair, the ICCAT Executive Secretary or his/her Assistant, bluefin tuna rapporteurs, and an outside expert with substantial experience in similar research undertakings for other tuna RFMOs, to guide and refine the Programme as necessary.

GBYP (Grand Bluefin Tuna Year Programme) was adopted as the official acronym of the research, which was initiated at the end of March 2010. It was divided in annual phases, sometimes covering parts of following years.

The project ICCAT-GBYP has meant and continues to mean the implementation of numerous scientific activities that contribute enormously to the knowledge of ABFT. These activities can be consulted under the tab 'Research' of the project web page.

Dr. Antonio Di Natale was the project coordinator between 2010 and 2018. Dr. Francisco Alemany took over from him in February 2018. 


\subsubsection{Symposium on Bluefin Tuna Traps Fisheries (ICCAT-GBYP 2011)}

The following is a literal transcription of some of the contents of the report (ICCAT 2012).

The aim of the Symposium was to discuss and review the information from tuna traps to maximize the use of scientific information provided by this traditional gear. The Symposium should also provide the opportunity to improve knowledge and achieve a better understanding of this ancient fishery in order to find a common methodological approach to standardize the CPUEs related to this fishing activity, which has the longest historical series among all the world's fisheries. Finding a common standardization procedure will allow these data series to be better used in the stock assessment models. Thus, this Symposium also represents an excellent opportunity to define the potential contribution of the trap fishery to the future work of the SCRS on the bluefin tuna stocks which should further help to improve the current management and conservation measures for bluefin tuna fisheries.

The Symposium was a response to a recommendation made by the Standing Committee on Research and Statistics (SCRS) in 2010 and was carried out within the framework of the ICCAT Atlantic-wide Research Program on Bluefin Tuna (GBYP).

The Symposium was open on May 23, 2011 by Dr. Pilar Pallarés, ICCAT Assistant Executive Secretary. Dr. Pallarés, on behalf of the Executive Secretary of ICCAT, thanked the Government of Morocco, the authorities of 4 Tangier and the National Institute of Marine Research for hosting the meeting, and welcomed the participants.

Dr. Pallarés made reference to the ICCAT Atlantic-wide Research Program on Bluefin Tuna (GBYP) within whose framework the Symposium was carried out and emphasized the importance of the trap fishery as a source of information on the history of bluefin tuna and its contribution to better understand the long-term dynamics of the population of this species. Dr. Pallarés expressed the wish that the Symposium will help the SCRS better assess the bluefin tuna stock and therefore contribute towards improving the management of the stocks.

Dr. José Luis Cort, Chair of the Symposium Scientific Committee, acted as Moderator for the Symposium. Dr. Cort acknowledged the kind support provided by the Moroccan tuna traps and the tuna industry for the organization of the Symposium and for hosting the official dinner. The Symposium was organized into four thematic sessions, each coordinated by a Moderator. The following participants acted as Moderators and Rapporteurs:

Moderators and Rapporteurs:

Session 1: A. Di Natale, M. Idrissi (ICCAT-GBYP)

Session 2: M. Ortiz (ICCAT)

Session 3: A. Fonteneau (IRD, France)

Session 4: Z. Suzuki (AFFRC, Japan).

A total of 58 scientists attended the Symposium.

The documents of the symposium are available at ICCAT (2012). 


\subsubsection{Session 1: Historical, Cultural and Technological Aspects of Bluefin Tuna Trap Fisheries}

The first Session included a total of eight presentations covering various aspects of this essential background.

SCRS/2011/036. Di Natale, A. An iconography of tuna traps: Essential information for the understanding of the technological evolution of this ancient fishery.

SCRS/2011/078. Garcia Garcia, F. Las almadrabas de la costa andaluza bajo el dominio de la casa ducal de Medina Sidonia. Su tipología, sus producciones y sus problemáticas.

SCRS/2011/071. Gil Pereira, J. Historical bluefin tuna catches from southern Portugal traps.

SCRS/2011/083. Manfrin, G., Mangano, A., Piccinetti, C., Piccinetti, R. Les données sur la capture des thons par les madragues dans l'archive du Prof. M. Sella.

SCRS/2011/069. Farrugio, H. Données historiques sur les anciennes madragues françaises de Méditerranée.

SCRS/2011/081. Abid, N. Benchoucha, S., Belcaid, S., Lamtai, A. and El Fanichi, $C$. Moroccan tuna traps: History and current situation.

SCRS/2011/031. López González, J.A., Ruiz Acevedo, J.M. Series históricas de capturas del bluefin tuna en las almadrabas del Golfo de Cádiz (Siglos XVI-XXI).

SCRS/2011/037. Di Natale, A. Literature on the eastern Atlantic and Mediterranean tuna trap fishery.

The discussion examined the fact that not all the Mediterranean areas are documented in the same way and the reason for that possibly reflects the fact that the trap fishery was perhaps not practiced in some east Mediterranean countries. Some data were provided in the 13th century by the famous geographer El Idrissi. It was noted that the detailed archives of the Ottoman Empire have not yet been analysed. The discussion also included historical information on the impact of killer whales on the fishery in the Strait of Gibraltar, the socioeconomic importance of the direct and indirect income derived from the tuna trap industry and the effects of having a series of tuna traps along the same coast. The high catches in the historical series are understandable, but it is more difficult to understand the reasons for the low catches. The mixture of species that are reported in the historical Duke of Medina Sidonia series will require additional data mining for further study. The conclusion of the session stressed the relevant importance of tuna traps from a cultural, historical and social point of view and the need to preserve this activity for the future. It was noted that historical data on trap fisheries require the identification of size classes, common names, size-class category, possible different species composition and market categories recorded, before combining multiple sets of data for these analyses. 


\subsubsection{Session 2: Bluefin Tuna Trap Data and Standardization for Assessment Uses}

The use of bluefin tuna trap fisheries data on catch, fishing effort and auxiliary information for assessment and stock assessment was presented and discussed during this session. A total of five papers were presented:

SCRS/2011/039. Ortiz, M., Palma, C., Pallarés, P., Kell, L., Idrissi, M. and Di Natale, $A$. Tuna trap data existing in the ICCAT database and data recovered under the GBYP. SCRS/2011/028. Cort, J.L., de la Serna, J. M. and Velasco, M. Annual mean weight of bluefin tuna (Thunnus thynnus) caught by the traps in the south of Spain between 1914-2010.

SCRS/2011/038. Di Natale, A. and Idrissi, M. Factors to be taken into account for a correct reading of tuna trap catch series.

SCRS/2011/027. Abid, N., de la Serna, J. M., Rodriguez Marín, E., Macías, D., Rioja, P., Ortiz de Urbina, J.M. Standardized CPUE of bluefin tuna (Thunnus thynnus) caught by Moroccan and Spanish traps for the period 1981-2009.

SCRS/2011/041. Kai, M. and Takeuchi, Y. Abundance index of young Pacific bluefin tuna (Thunnus orientalis) estimated from the Japanese set net fishery's data.

The general discussion commented on the importance of the trap fisheries as a major source of scientific and fisheries data for the assessment of bluefin tuna stocks and the need to continue supporting the scientific collection and reporting of data from trap operations. It was noted that management measures, such as quota restrictions, need to be taken into account for data collection and data analysis. Therefore, there is a need to record retained as well as released fish from traps, and to have standard descriptions of fishing operations to define clearly the fishing effort unit. In addition to the CPUE series from trap catches, size and age distribution samples should be routinely collected. Analyses from traps in southern Spain have shown the change in the trends of size and age of fish caught among various series of years. In such cases it is recommended that the CPUE series be standardized by age or age-groups for the assessment process. It was also recommended that analyses of trap fishery data be carried out on a wider regional scale, including coordination of the potential links between overall environmental trends (currents, decadal oscillations, etc.).

It is also important to understand the effects of small scale meteorological events on the catch rates of local traps.

\subsubsection{Session 3: Tuna Traps as a Reliable Scientific Observatory for Bluefin Tuna Stocks}

Six presentations were given during this session. They presented results of scientific value obtained from a wide range of historical and currently active traps, mainly from the Mediterranean Sea. 
SCRS/2011/075. Addis, P., Secci, M., Locci, I., Sabatini, A., Dean, J. M. and Cau, A. Long-term analysis (1993-2010) of the catches of Atlantic bluefin tuna (Thunnus thynnus) from the traditional trap fisheries of Sardinia.

SCRS/2011/0074. Dean, J. M., Andrushchenko, I. and Neilson, J. D. The western Atlantic bluefin tuna trapnet fishery.

SCRS/2011/042. Suzuki, Z. and Kai, M. Movement of Atlantic bluefin tuna toward the Strait of Gibraltar inferred from Japanese longline data.

SCRS/2011/029. De la Serna, J. M., Macías, D., Ortiz de Urbina, J. M., RodríguezMarín, E., Abascal, F. Study on the eastern Atlantic and Mediterranean bluefin tuna stock using the Spanish traps as scientific observatories.

SCRS/2011/084. Fonteneau, A. Mediterranean traps in the 21st century: Research tools for the conservation of bluefin tuna.

SCRS/2011/080. Cannas, R., Ferrara, G., Milano, I., Landi, M., Cariani, A., Addis, P., Cau, A., Piccinetti, C., Sella, M., Tinti, F. Spatio-temporal genetic variation of Atlantic bluefin tunas from Sardinian and Mediterranean tuna traps.

The general conclusion following these presentations and the discussion was a firm consensus that for ICCAT scientists bluefin tuna traps were for four centuries, and remain today, an invaluable gold-mine of data (statistical, biological and others), while recent fishing mortality due to tuna traps is low and the sizes of bluefin tuna caught by the traps is close to the optimum in terms of yield per recruit. On the other hand, ICCAT scientists recognize that the statistical and scientific information obtained from modern and recent gears (such as purse seiners) is and has been extremely limited, particularly for a period during which these modern gears have been the major source of excessive fishing mortality suffered by the bluefin tuna stock.

In this context, these data from traps are as essential today as they were in the past for ICCAT bluefin tuna stock assessment, because they provide age-specific measures of stock biomass for both the sedentary and migrating fraction of the bluefin tuna stock, and also a wide range of biological data that constitute a very important component in the bluefin tuna stock assessment models.

There is a consensus among scientists that it would be very negative to stop now, after 400 years of continuous data, these unique statistical series from the trap fisheries. The recommendation from this Symposium to the ICCAT Commission and to the ICCAT CPCs is to maintain the trap fisheries operational, inter alia because of their high value for scientific research and stock assessment. The Symposium participants also recommended that these traps should be kept open for a period that allows the continuation of their long-term statistical series.

It is also recommended that these traps be considered as "ICCAT tuna observatories", increasing their cooperation with ICCAT and its scientific programs by providing full access to their detailed catch and effort data, giving access to biological sampling and allowing the tag and release of bluefin tunas. 


\subsubsection{Session 4: Tuna Traps and Bluefin Tuna: Socio-Economy, Global Management and Market Issues}

There were four documents presented at this Session:

SCRS/2011/040. Suzuki, Z., Kai, M. General information on Japanese trap fisheries catching Pacific bluefin tuna (Thunnus orientalis): Fishery and socio-economic roles. SCRS/2011/082. Malouli Idrissi, M., Zahraoui, M. Nhhala, H. Les madragues au Maroc: Aspects économiques.

SCRS/2011/076. Addis, P., Secci, M., Locci, I., Cannas, R., Greco, G., Dean, J. M., $\mathrm{Cau}, \mathrm{A}$. Social, cultural and basic economic analysis of the trap fishery of Sardinia: First step towards parameterization.

SCRS/2011/077. Addiss, P., Secci, M., Locci, I. Cau, A. Harvesting, handling practices and processing of bluefin tuna captured in the trap fishery: Possible effects on the flesh quality.

Discussions centred on the following:

As concerns the Japanese trap presentation, it was asked whether or not the Japanese government gave preferential treatment to traditional fisheries such as the traps with respect to management of the stock. The answer was that it did not give any special treatment to the traditional fisheries but there appeared to be general agreement that the traditional fisheries should be less affected by the regulatory measures because their fisheries had been sustainably conducted.

Clarification was made to the fact that fuel cost is a dominant item of expenditure in the Moroccan trap fishery and it was explained that the reason for the high fuel cost in total expenditure was due to the long distance between the ports and trap locations and to the trap setting-up operations, which require considerable time and effort.

Some concern was raised about using the "matanza" (killing of bluefin in the final stage of trap harvest) as a tourist attraction. Although there were no complaints from the tourists who watched the "matanza", it may be necessary for persons in charge of the trap fishery to be prepared to give an explanation of this activity.

A question was raised about the cooperation among trap owners and scientists who collect biological samples and the response was that most of the sampling is permitted although it depends to a large extent on the kind of samples taken. It was noted that maintaining a good relationship with the industry is important and this may be done through feedback to the industry from the scientific research results obtained by biological sampling. It was agreed that the proposals made by the tuna trap industry be included as Appendix 3 of the report in a summarized format.

\subsubsection{Recommendations}

- The historical data series from the tuna trap fishery archives that have been recovered in the last two years provide an important improvement to the ICCAT data base. The Symposium recommends that further details be made available by 
national scientists for a better understanding of the natural fluctuations of the stock and to improve standardised CPUEs taking into account the most relevant variables.

- The considerable historical and cultural importance of the tuna trap fishery and industry shall be preserved. The Symposium recommends that the national governments concerned take the necessary steps to promote the urgent conservation of the few remaining tuna traps by considering, among others, the possibility of requesting their inclusion under "World Cultural Heritage" by UNESCO.

- It is also recommended that these traps be considered as "ICCAT Tuna Observatories" by increasing their full cooperation with ICCAT and its scientific programs, providing full access to their detailed catch and effort data, permitting biological sampling to be carried out, and by allowing the tag and release of bluefin tunas.

- For the opportunity to effectively use the tuna traps as "Tuna Scientific Observatories" the Symposium reiterates the recommendation from the SCRS in 2010 to the Commission to establish a scientific quota allocation for the ICCAT Atlantic-Wide Research Program on Bluefin Tuna (GBYP). This allocation should not fall under the restrictions of current size regulations and should include all fish-size ranges.

- For standardizing the CPUE series from trap fisheries, it is recommended that:

- Records be kept of landed fish as well as fish released from the traps.

- Records be kept of size and/or age information of the fish caught, and indices be developed by age or age groups if there are changes in the size distribution of fish caught in the traps.

- Regional-wide studies be promoted on the trends of catch rates at size-age from different tuna traps.

- There is a consensus among scientists that it would be very negative to stop now, following 400 years of continuous data, these unique statistical series from the trap fisheries. The recommendation from this Symposium to the Commission and to the ICCAT CPCs is to maintain the trap fisheries operational, inter alia, because of their high value to scientific research and stock assessment.

- The Symposium participants also recommended that these traps be kept open for a time period long enough to maintain the consistency of their long-term statistical series.

\subsubsection{Adoption of the Report and Closure}

Dr. José Luis Cort, the Moderator of the Symposium, thanked the participants for the exceptional work carried out and expressed special appreciation to the Secretariat and, in particular, to the GBYP for the excellent organization of the Symposium.

The report of the Symposium was adopted. The Symposium was adjourned on May 25, 2011.

Following this general presentation of ABFT and its fishing, the aim of the present article is to study the Bay of Biscay fishery in detail. This fishery is one of those that has been the subject of the largest number of studies and the authors of the present paper have recently published a study on it (Cort and Abaunza, 2015) describing the interaction of the fishery with the other spawner fisheries in the eastern Atlantic. 


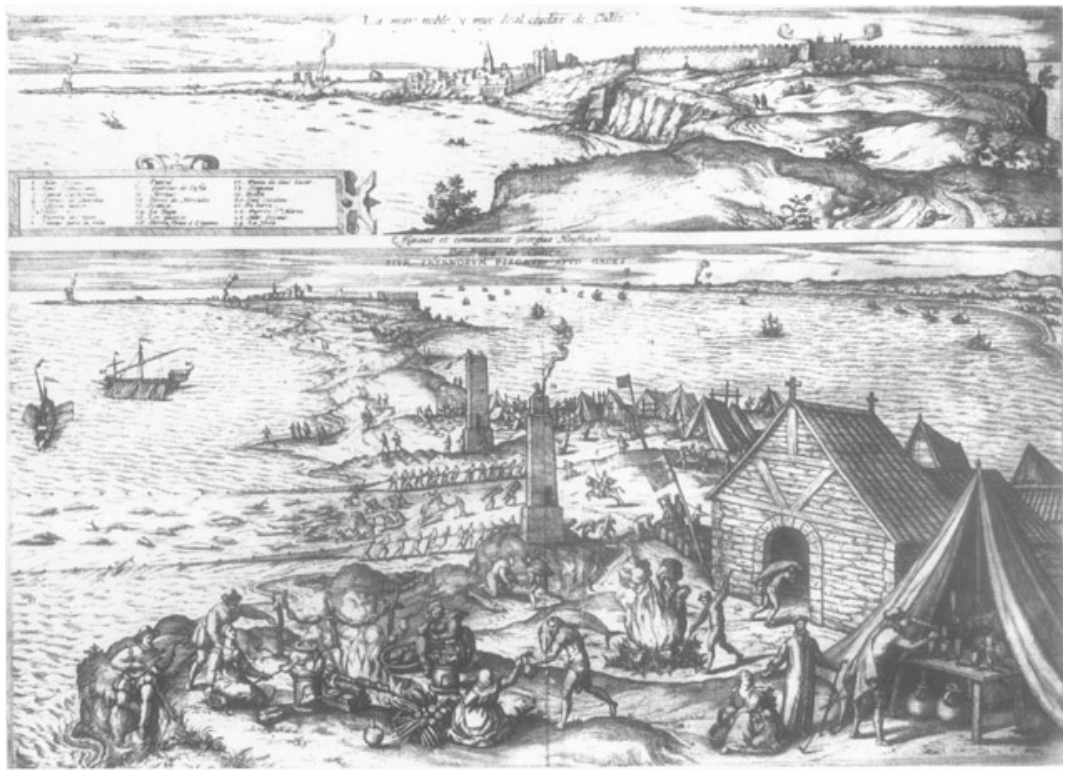

Representation of bluefin tuna fishing in Cádiz (16th century). Taken from Di Natale (2012); ICCAT (2012)

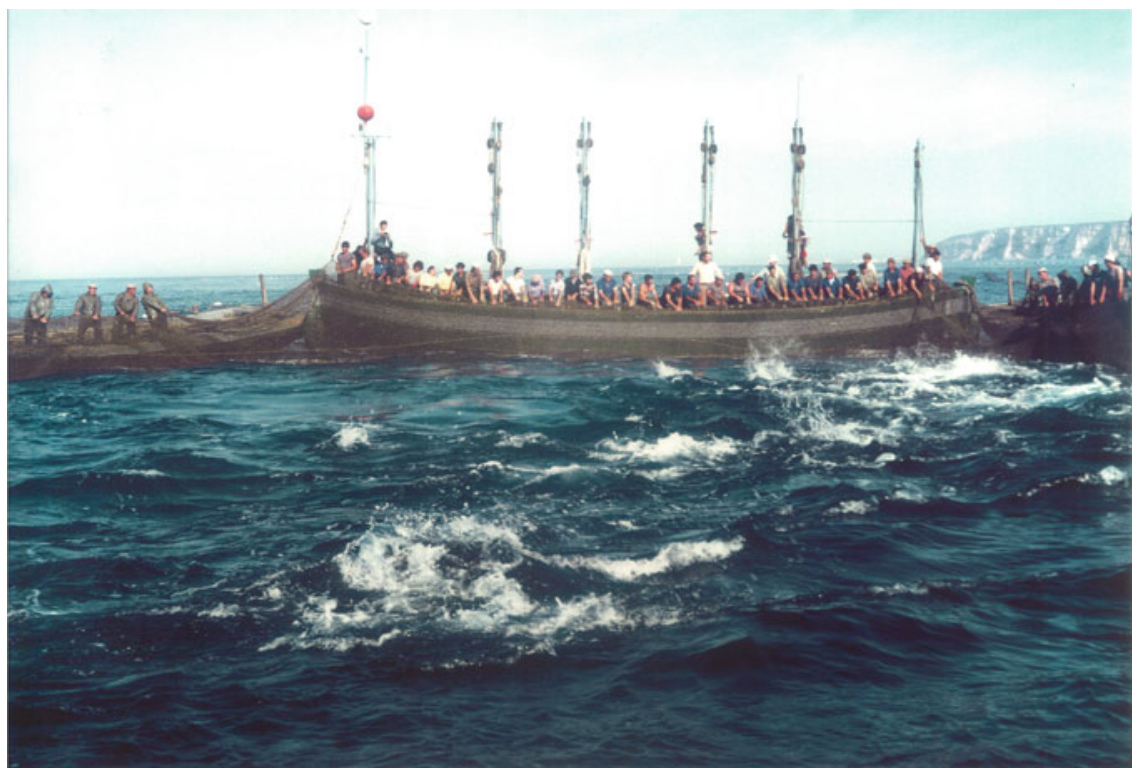

End phase in the trap fishing operation: la levantada ("the lifting"), 1982 (Documentary archive, IEO) 


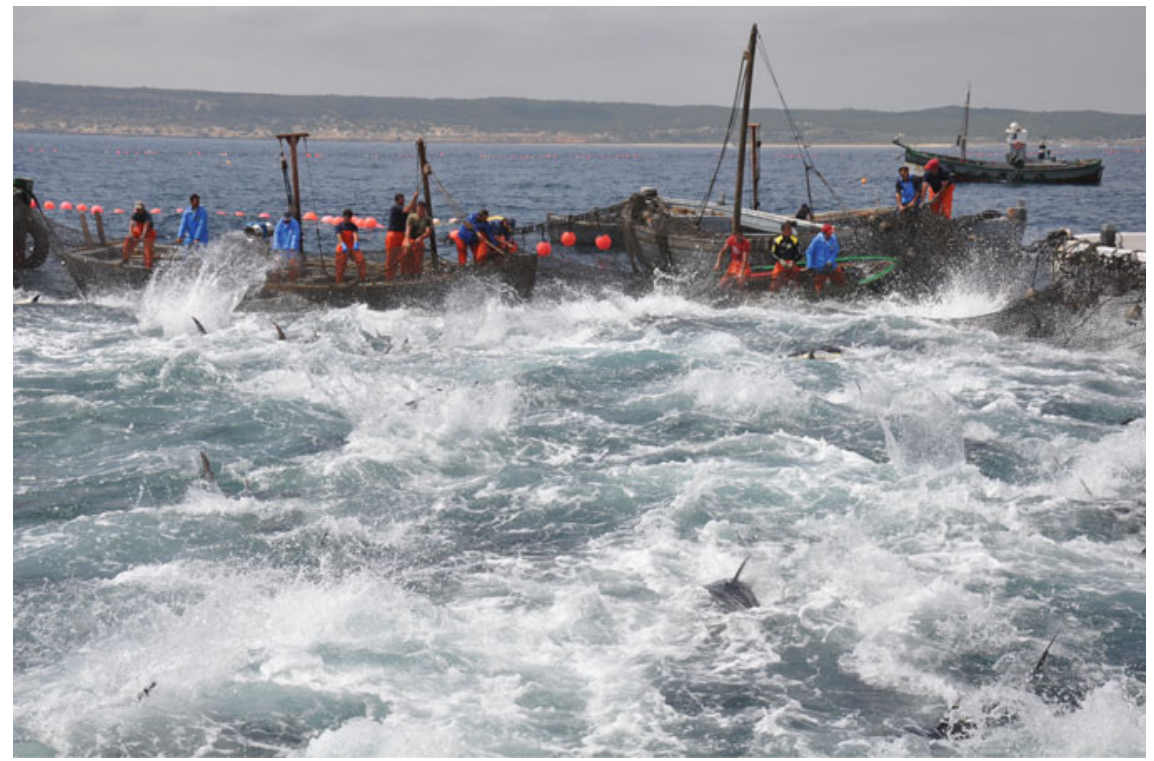

"Death chamber" (2009)

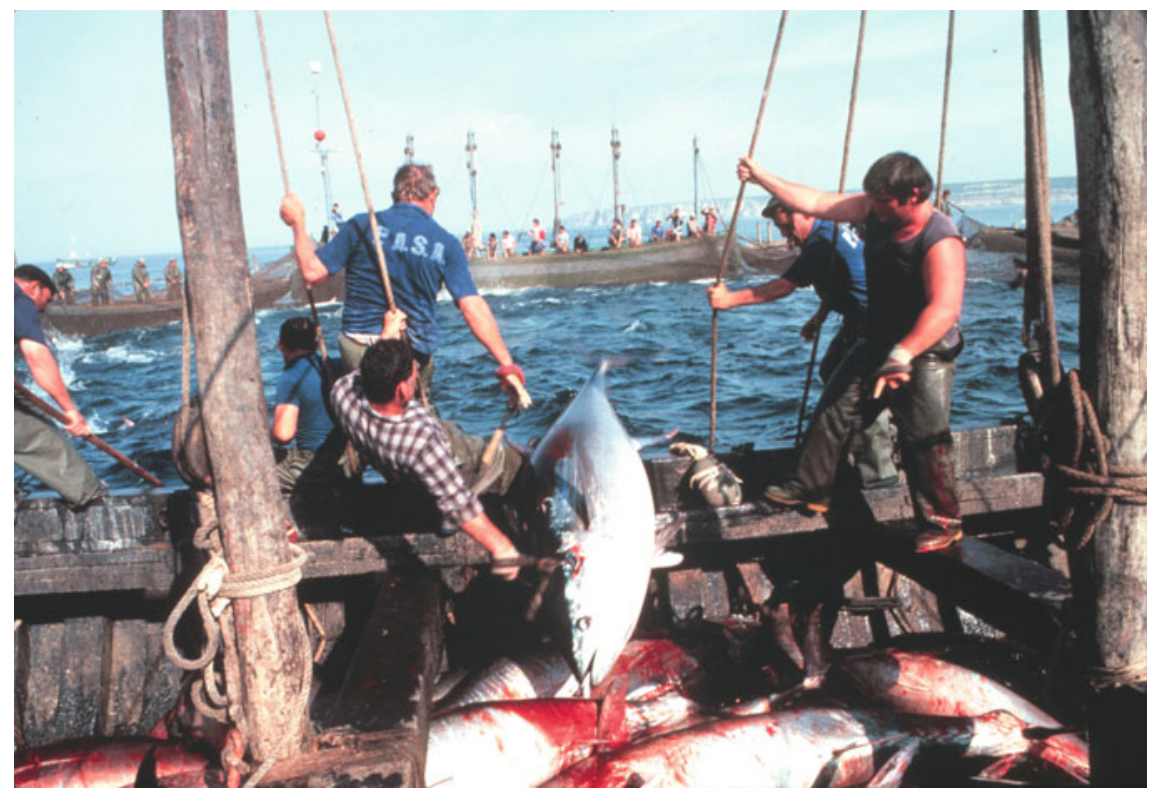

Raising the tunas with hooks (1982) (http://www.photolib.noaa.gov/bigs/fish2017.jpg) (Documentary archive, IEO) 


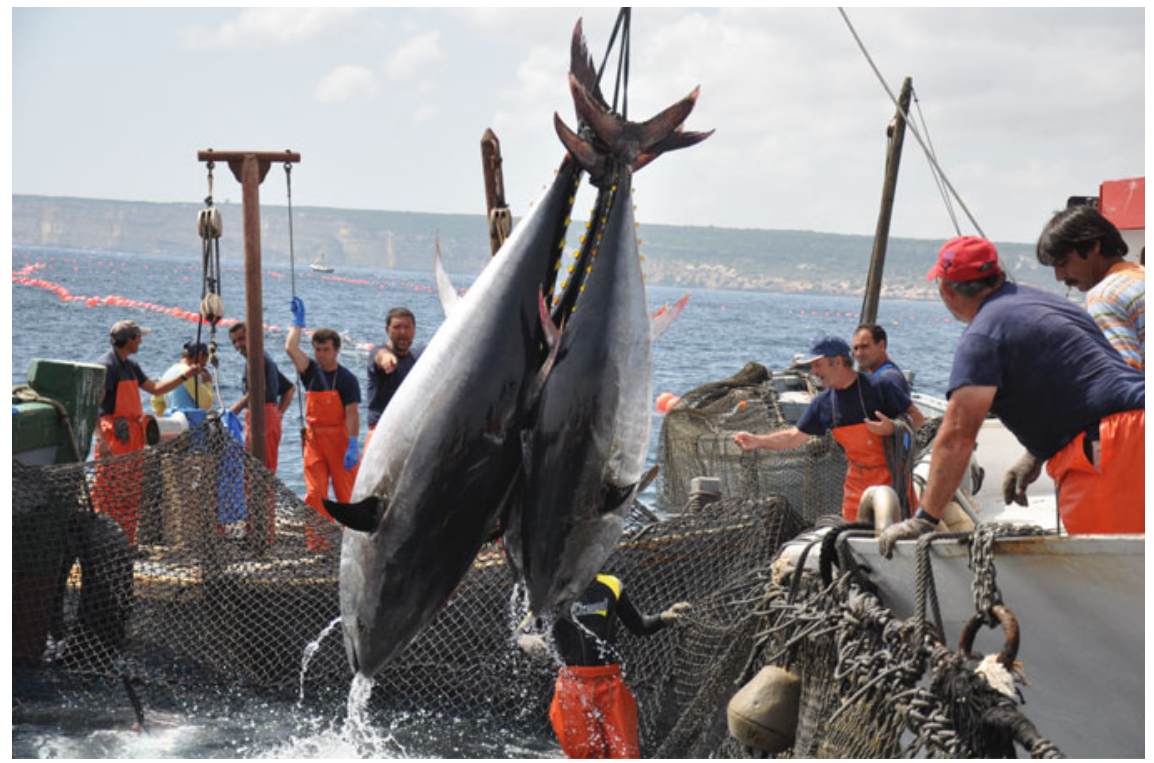

Tuna trap of Barbate, 2009 (Cádiz, Spain) (Documentary archive, IEO)

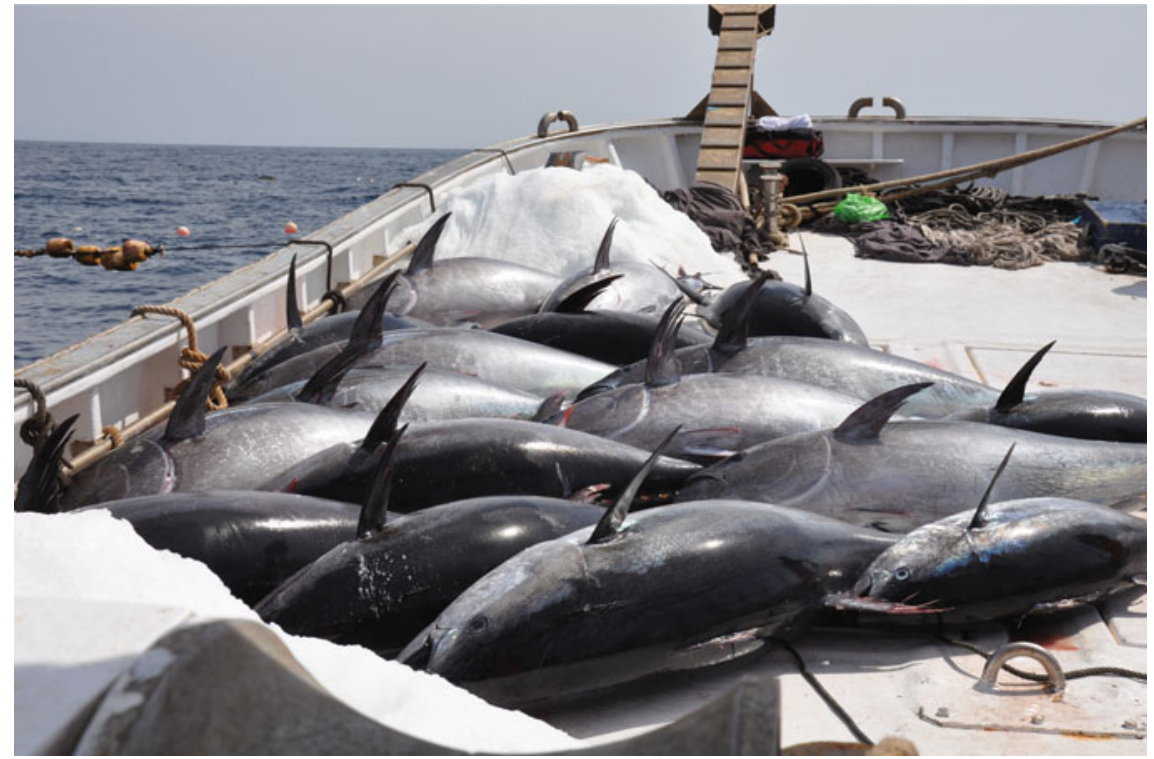

Bluefin tuna catch in the trap of Barbate, 2009 (Cádiz, Spain) (Documentary archive, IEO) 


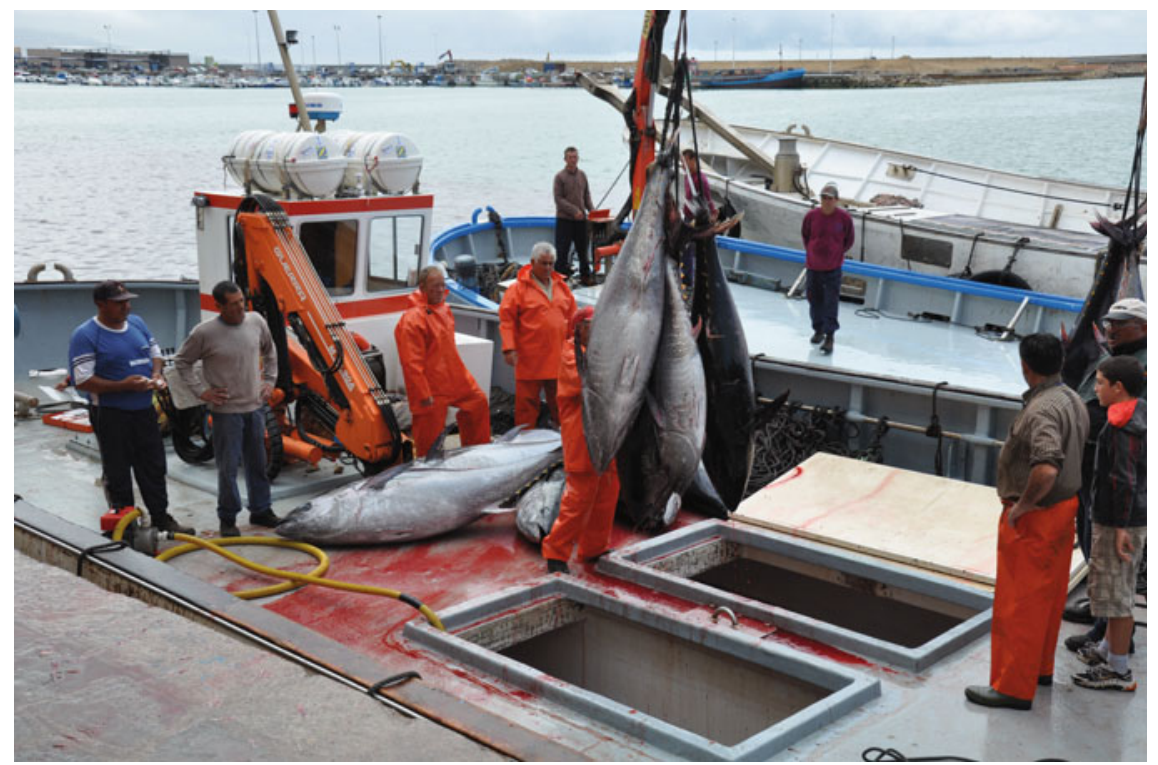

Landing the catches of the trap of Barbate, 2009 (Cádiz, Spain) (Documentary archive, IEO)

\section{References}

Abascal F, Medina A, de la Serna JM, Godoy D, Aranda G (2016) Tracking bluefin tuna reproductive emigration into the Mediterranean Sea with electronic pop-up satellite archival tags using two tagging procedures. Fish Oceanogr 25(1):54-66

Addis P, Secci M, Biancacci C, Loddo D, Cuccu D, Palmas F, Sabatini A (2016) Reproductive status of Atlantic bluefin tuna, Thunnus thynnus, during migration off the coast of Sardinia (western Mediterranean). Fish Res 181:137-147

Ailloud LE, Lauretta MV, Hanke A, Golet W, Allman R, Siskey MR, Secor DH, Hoening JM (2017) Improving growth estimates for Western Atlantic bluefin tuna using an integrated modeling approach. Fish Res 191:17-24

Alemany F, Quintanilla L, Vélez-Belchí P, García A, Cortés D, Rodríguez JM et al (2010) Characterization of the spawning habitat of Atlantic bluefin tuna and related species Balearic Sea (western Mediterranean). Prog. Oceanogr 86:21-38

Álvarez-Berastegui D, Ciannelli L, Aparicio-Gonzalez A, Reglero P, Hidalgo M et al (2014) Spatial scale, means and gradients of hydrographic variables define pelagic seascapes of bluefin and bullet tuna spawning distribution. PLoS ONE 9 (10):e109338. https://doi.org/10.1371/journal. pone.0109338[pmc free article][PubMed]

Anonymous (1994) An assessment of Atlantic bluefin tuna. National Academy Press, Washington, D.C. $148 \mathrm{p}$

Aranda G, Abascal FJ, Varela JL, Medina A (2013) Spawning behaviour and post-spawning migration patterns of Atlantic bluefin tuna (Thunnus thynnus) ascertained from satellite archival tags. PLoS ONE 8(10):e76445. https://doi.org/10.1371/journal.pone.0076445

Baglin REJ (1982) Reproductive biology of western Atlantic bluefin tuna. Fish Bull 80:121-134 
Battaglia P, Andaloro F, Consoli P, Esposito V, Malara D, Musolino S, Pedà C (2013) Feeding habits of the Atlantic bluefin tuna, Thunnus thynnus (L. 1758), in the central Mediterranean Sea (Strait of Messina). Helgol Mar Res 67(1):97-107. https://doi.org/10.1007/s10152-012-0307-2

Block BA, Teo SLH, Walli A, Boustany A, Stikesbury MJW, Farwell CJ, Weng KC, Dewar H, Williams TD (2005) Electronic tagging and population structure of Atlantic bluefin tuna. Nature 434:1121-1127

Brêthes JC (1978) Campagne de marquage de jeunes thons rouges au large des côtes du Maroc. Col Vol Sci Pap ICCAT 7:313-317

Brêthes JC (1979) Sur les premiers recuperations des thons rouges marqués en juillet 1977 au large du Maroc. Col Vol Sci Pap ICCAT 8:367-369

Brêthes JC, Mason JM Jr (1979) Bluefin tuna tagging off the Atlantic coast of Morocco in 1978. Col Vol Sci Pap ICCAT 8:329-332

Brodziak J, Ianelli J, Lorenzen K, Methot RD Jr (2011) Estimating natural mortality in stock assessment applications. NOAA Technical Memorandum NMFS-F/SPO-119; $48 \mathrm{p}$

Brophy D, Haynes P, Arrizabalaga H, Fraile I, Fromentin JM, Garibaldi F, Katavic I, Tinti F, Karakulak S, Macías D, Busawon D, Hanke A, Kimoto A, Sakai O, Deguara S, Abid N, Neves Santos M (2015) Otolith shape variation provides a marker of stock origin for north Atlantic bluefin tuna (Thunnus thynnus). Mar Freshw Res. http://dx.doi.org/10.1071/MF15086

Butler MJA, Accy JF, Dickson CA, Hunt JJ, Burnet CD (1977) Apparent age and growth, based on otoliths analysis, of giant bluefin tuna (Thunnus thynnus thynnus) in the 1975-76 Canadian catch. Col Vol Sci Pap ICCAT 6:318-330

Butler CM, Logan JM, Pravaznik JM, Hoffmayer ER, Staudinger MD, Quattro JM, Roberts MA, Ingram GW Jr, Pollack AG, Lutcavage ME (2015) Atlantic bluefin tuna Thunnus thynnus feeding ecology in the northern Gulf of Mexico: a preliminary description of diet from the western Atlantic spawning grounds. J Fish Biol 86(1):365-374. https://doi.org/10.1111/jfb.12556

Caddy JF, Dickson CA, Butler JA (1976) Age and growth of giant bluefin tuna (Thunnus thynnus thynnus) taken in Canadian waters in 1975. J Fish Res Board Can, MS Rep. No. 1395

Cermeño P, Quílez-Badia G, Ospina-Álvarez A, Sainz-Trápaga S, Bustany AM, Seitz AC, Tudela S, Block BA (2015) Electronic tagging of Atlantic bluefin tuna (Thunnus thynnus, L.) reveals hábitat use and behaviors in the Mediterranean Sea. PLoS ONE 10(2):e0116638. https://doi.org/ 10.1371/journal.pone.0116638

Compeán-Jiménez G, Bard FX (1983) Growth increments on dorsal spines of eastern Atlantic bluefin tuna (Thunnus thynnus (L.)) and their possible relation to migrations patterns. NOAA, Tech Rep NMFS 8:77-86

Corriero A, Kakakulak S, Santamaría N, Deflorio M, Spedicato D, Addis P, Fenech-Farrugia A, Vassallo-Agius R, de la Serna JM, Oray I, Cau A, De Metrio G (2005) Size and age at sexual maturity of femelle bluefin tuna (Thunnus thynnus L. 1758) from the Mediterranean Sea. J Appl Ichthyol 21:483-486

Cort JL (1990) Biología y pesca del atún rojo, Thunnus thynnus (L.), del mar Cantábrico. Doctoral thesis. Publicaciones especiales, IEO, vol 4, $272 \mathrm{p}$

Cort JL, Arregui I, Estruch V, Deguara S (2014) Validation of the growth equation applicable to the eastern Atlantic bluefin tuna, Thunnus thynnus (L.), using $L_{\max }$, tag-recapture and first dorsal spine analysis. Rev Fish Sci Aquac 22(3):239-255. https://doi.org/10.1080/23308249.2014.931173

Cort JL, Deguara S, Galaz T, Mèlich B, Artetxe I, Arregi I et al (2013) Determination of $L_{\max }$ for Atlantic bluefin tuna, Thunnus thynnus (L.), from meta-analysis of published and available biometric data. Rev Fish Sci 21(2):181-212. https://doi.org/10.1080/10641262.2013.793284

Cort JL, Estruch VD, Santos MN, Di Natale A, Abid N, de la Serna JM (2015) On the variability of the length-weight relationship for Atlantic bluefin tuna, Thunnus thynnus (L.). Rev Fish Sci Aquac 23(1):23-38. https://doi.org/10.1080/23308249.2015.1008625

Cort JL, Nøttestad L (2007) Fisheries of bluefin tuna (Thunnus thynnus) spawners in the Northeast Atlantic. Col Vol Sci Pap ICCAT 60:1328-1344

De Buen F (1925) Biología del atún, Orcinus thynnus (L.). Resultado de las campañas realizadas por acuerdos internacionales, 1. Madrid, $118 \mathrm{p}$ 
De la Serna JM, Abid AN, Godoy D (2013) Posible influencia sobre el comportamiento migratorio del atún rojo (Thunnus thynnus) de las distintas estrategias de marcado electrónico utilizadas en las almadrabas y jaulas de engorde. Col Doc Sci Pap ICCAT, 69:427-434

De Metrio G, Arnold GP, Block BA, de la Serna JM, Deflorio M, Cataldo M, Yannopoulos C, Megalofonou P, Beeper S, Farwell C, Seitz A (2002) Behaviour of post-spawning Atlantic bluefin tuna tagged with pop-up satellite tags in the Mediterranean and eastern Atlantic. Col Vol Sci Pap ICCAT 54(2):415-424

Dicenta A, Piccinetti C (1980) Comparison between the estimated reproductive stocks of bluefin tuna (T. thynnus) of the Gulf of Mexico and western Mediterranean. Col Vol Sci Pap ICCAT 9(2):442-448

Di Natale A (2012) Literature on eastern Atlantic and Mediterranean tuna trap fishery. Col Vol Sci Pap ICCAT 67:175-220

Di Natale A, Tensec S, Pagá A (2016) Preliminary information about the ICCAT GBYP tagging activities in phase 5. Col Vol Sci Pap ICCAT 72(6):1589-1613

Druon JN, Fromentin JM, Aulanier F, Heikkonen J (2011) Potential feeding and spawning habitats of Atlantic bluefin tuna in the Mediterranean Sea. Mar Ecol Prog Ser 439:223-240. https://doi. org/10.3354/meps09321

Druon JN, Fromentin JM, Hanke AR, Arrizabalaga H, Damalas D, Tičina V et al (2016) Habitat suitability of the Atlantic bluefin tuna by size class: an ecological niche approach. Progr Oceanogr 142:30-46. https://doi.org/10.1016/j.pocean.2016.01.002

Duclerc J, Sachi J, Piccinetti-Manfrin G, Piccinetti C, Dicenta A, Barrois JM (1973) Nouvelles données sur la reproduction du thon rouge (Thunnus thynnus) et d'autres espèces des thonidés en Mediterranée. Rev Trav Inst Pêches Marit 37(2):163-176

Estrada JA, Lutcavage M, Thorrold SR (2005) Diet and trophic position of Atlantic bluefin tuna (Thunnus thynnus) inferred from stable carbon and nitrogen isotope analysis. Mar Biol 147:37-45. https://doi.org/10.1007/s00227-004-1541-1

Florido del Corral D (2013) Las almadrabas andaluzas bajo el consorcio nacional almadrabero (1928-1971): aspectos socio-culturales y políticos. Semana, Ciencias Sociais e Humanidades 25:117-151. ISSN 1137-9669

Florido del Corral D, Santos A, Ruiz JM, López JA (2018) Las almadrabas suratlánticas andaluzas. Historia, tradición y patrimonio (siglos XVIII-XXI). Editorial Universidad se Sevilla, 328 p. ISBN 978-84-472-1885-1

Fonteneau A, Le Person A (2009) Bluefin fishing in Lannion Bay, northern Brittany, during the 1946-1953 period. Col Vol Sci Pap ICCAT 63:69-78

Fonteneau A, Maguire JJ (2014) On the natural mortality of eastern and western bluefin tuna. Col Vol Sci Pap ICCAT 70(1):289-298

Frade F (1938) Recherches sur la maturité sexuelle du thon rouge de 1'Atlantique et de la Mediterranée. Bul Soc Portug Sci Nat 12:243-250

Fraile I, Arrizabalaga H, Rooker R (2014) Origin of Atlantic bluefin tuna (Thunnus thynnus) in the Bay of Biscay. ICES J Mar Sci. https://doi.org/10.1093/icesjms/fsu156

Fraser K (2008) Possessed. World Record Holder for Bluefin Tuna. Kingstown, Nova Scotia: T \& $\mathrm{S}$ Office Essentials and printing, $243 \mathrm{p}$

Fromentin JM (2002) Final report of STROMBOLI-EU-DG XIV project 99/022. In: European Community-DG XIV, Brussels, $109 \mathrm{p}$

Fromentin JM (2009) Lessons from the past: investigating historical data from bluefin tuna fisheries. Fish Fish 10:197-216

Fromentin JM, Bonhommeau S, Arrizabalaga H, Kell LT (2014) The spectre of uncertainty in management of exploited fish stocks: the illustrative case of Atlantic bluefin tuna. Marine Policy 47:8-14

Fromentin JM, Powers J (2005) Atlantic bluefin tuna: population dynamics, ecology, fisheries and management. Fish Fish 6:281-306 
Fromentin JM, Restrepo V (2009) A year-class curve analysis to estimate mortality of Atlantic bluefin tuna caught by the Norwegian fishery from 1956-1979. Col Vol Sci Pap ICCAT 64(2):480-490

Galuardi B, Logan JM, Neilson JD, Lutcavage M (2015) Complex migration routes of Atlantic bluefin tuna (Thunnus thynnus) question current population structure paradigm. Can J Fish Aquatic Sci 966-976

García A, Alemany F, de la Serna JM, Oray I, Karakulak S, Rollandi L, Arigo A, Mazzola S (2005) Preliminary results of the 2004 bluefin tuna larval surveys off different Mediterranean sites (Balearic Archipelago, Levantine Sea, and the Sicilian Channel). Col Vol Sci Pap ICCAT 58:1420-1428

García A, Cortés D, Ramírez T, Fehri-Bedoui R, Alemany F, Rodríguez JM, Carpena Á, Álvarez JP (2006) First data on growth and nucleic acid and protein content of field-captured Mediterranean bluefin (Thunnus thynnus) and albacore (Thunnus alalunga) tuna larvae: a comparative study. Scientia Marina 70(S2). https://doi.org/10.3989/scimar.2006.70s267

Goñi N, Fraile I, Arregui I, Santiago J, Boyra G, Irigoien X, Lutcavage M et al (2010) On-going bluefin tuna research in the Bay of Biscay (Northeast Atlantic): The "Hegalabur 2009" project. Col Vol Sci Pap ICCAT 65(3):755-769

Goñi N, Onandia I, López J, Arregui I, Uranga J, Melvin GD, Boyra G, Arrizabalaga H, Santiago J (2017) Acoustic-based fishery-independent abundance index of juvenile bluefin tunas in the Bay of Biscay. Col Vol Sci Pap ICCAT 73(6):2044-2057

Heinisch G, Rosenfeld H, Knapp JM, Gordin H, Lutcavage ME (2014) Sexual maturity in western Atlantic bluefin tuna. Sci Rep 4, Article number: 7205. https://doi.org/10.1038/srep07205

ICCAT (1996) National report of Japan. ICCAT Report for biennial period, 1996-97. Part I, vol. 2, 204 p. http://iccat.int/Documents/BienRep/REP_EN_96-97_I_2.pdf

ICCAT (2007) Report for biennial period, 2006-07. Part I (2006). Vol. 2, 240 p. https://www.iccat. int/Documents/BienRep/REP_EN_06-07_I_2.pdf

ICCAT (2008) Report for biennial period, 2006-07. Part II (2007). Vol. 1, 276 p

ICCAT (2009) Report of the world symposium for the study into the stock fluctuation of northern bluefin tunas (Thunnus thynnus and Thunnus orientalis), including the historical periods. Col Vol Sci Pap ICCAT 63:1-49

ICCAT (2010) ICCAT Manual. Description of species. Chapter 2; 2.1 .5 Atlantic bluefin tuna, vol 99. Madrid, ICCAT, pp 93-111 http://iccat.int/Documents/SCRS/Manual/CH2/2_1_5_BFT_ ENG.pdf

ICCAT (2012) ICCAT-GBYP symposium on trap fisheries for bluefin tuna. Col Vol Sci Pap ICCAT $67: 3-30$

ICCAT (2017) Report of the 2017 ICCAT bluefin stock assessment meeting. Madrid, Spain, 22-27 July 2017, 106 p. http://iccat.int/Documents/Meetings/Docs/2017_BFT_ASS_REP_ENG.pdf

Hamre J (1960) Tuna investigation in Norwegian coastal waters 1954-1958. Ann Biol Cons Int Expl Mer 15:197-211

Hamre J (1965) The Norwegian tuna investigations, 1962-1963. Ann Biol Cons Int Expl Mer 20:232-236

Hamre J, Tiews K (1963) Second report of the bluefin tuna working group. ICES, C.M. 1963 Scombriform Fish Committee, no. 14, 29 p

Karakulak S, Oray I, Corriero A, Deflorio M, Santamaria N, Desantis S, De Metrio G (2004) Evidence of a spawning area for the bluefin tuna (Thunnus thynnus) in the Eastern Mediterranean. J Appl Ichthyol 20:318-320

Laiz-Carrión R, Gerard T, Uriarte A, Malca E, Quintanilla JM, Muhling B, Alemany F, Privoznik SL, Shiroza A, Lamkin JT, García A (2015) Trophic ecology of Atlantic bluefin tuna (Thunnus thynnus) larvae from the Gulf of Mexico and NW Mediterranean spawning grounds: a comparative stable isotope study. PLoS ONE 10(7):2015. https://doi.org/10.1371/journal.pone0133406

Lamboeuf M (1975) Contribution a la connaissance des migrations des jeunes thons rouges a partir du Maroc. Col Vol Sci Pap ICCAT 4:141-144 
Logan JM, Rodríguez-Marín E, Goñi N, Barreiro S, Arrizabalaga H, Golet WJ, Lutcavage M (2010) Diet of young Atlantic bluefin tuna (Thunnus thynnus) in eastern and western foraging gound. Mar Biol 12. https://doi.org/10.1007/s00227-010-1543-0

Lozano F (1958) Los escómbridos de las aguas españolas y marroquíes y su pesca. Trab Inst Esp Ocean 25:254 p

Lozano F (1959) The usu of echo-sondeurs in the study of the migrations of tuna. Proc Gen Fish Coun Medit 5:101-104

Luque P, Rodríguez-Marín E, Landa J, Ruiz M, Quelle P, Macías D, Ortiz de Urbina JM (2014) Direct ageing of Thunnus thynnus from the eastern Atlantic Ocean and western Mediterranean Sea using dorsal fin spines. J Fish Biol 84:1876-1903

Lutcavage M, Kraus SD (1995) The feasibility of direct photographic aerial assessment of giant bluefin tuna in New England waters. Fish Bull 93:495-503

Lutcavage M, Kraus SD, Hoggard W (1997) Aerial assessment of giant bluefin tuna in the Bahama Banks-Straits of Florida, 1995. Fish Bull 95:300-310

Lutcavage M, Galuardi B, Lam TCH (2013) Predicting potential Atlantic spawning grounds of western Atlantic bluefin tuna based on electronic tagging results, 2002-2011. Col Vol Sci Pap ICCAT 69:955-961

MacKenzie BR, Payne MR, Boje J, Hoyer JL, Siegstad H (2014) A cascade of warming impacts brings bluefin tuna to Greenland waters. Glob Change Biol 20(8):2484-2491

Manfrin G, Mangano A, Piccinetti C, Piccinetti R (2012) Les données sur la capture des thons par les madragues dans l'archive du prof Sella. Col Vol Sci Pap ICCAT 67:106-111

Mather III FJ, Mason Jr JM, Jones AC (1973) Distribution fisheries and life history data relevant to identification of Atlantic bluefin tuna stocks. Col Vol Sci Pap ICCAT 2:234-258

Mather III FJ, Mason Jr JM, Jones AC (1995) Historical document: life history and fisheries of Atlantic bluefin tuna. In: NOAA technical memorandum, NMFS-SEFSC-370, Miami Fl, 165 p

Medina A, Abascal FJ, Megina C, García A (2002) Stereological assessment of the reproductive status of female Atlantic northern bluefin tuna during migrations to Mediterranean spawning grounds through the Strait of Gibraltar. J Fish Biol 60:203-217. https://doi.org/10.1111/j.10958649.2002.tb02398.x

Medina A, Cort JL, Aranda G, Varela JL, Aragón L, Abascal F (2011) Summary of bluefin tuna tagging activities carried out between 2009 and 2010 in the East Atlantic and Mediterranean. Col Vol Sci Pap ICCAT 66(2):874-882

Melvin GD (2016) Observations of in situ Atlantic bluefin tuna (Thunnus thynnus) with 500-kHz multibeam sonar. ICES J Mar Sci 73(8):1975-1986. https://doi.org/10.1093/icesjms/fsw077

Pereira J (2012) Historical bluefin tuna catches from southern Portugal traps. Col Vol Sci Pap ICCAT 67:88-105

Picinetti C, Piccinetti-Manfrin G (1970) Osservazioni sulla biologia dei primi stadi giovanili del tonno (Thunnus thynnus, L.). Boll Pesca Piscic Idrobiol (25):223-247

Piccinetti C, Piccinetti-Manfrin G, Soro S (1997) Résultats d'une campane de recherche sur les larves de thonidés en Mediterranée. Col Vol Sci Pap ICCAT 46:207-214

Puncher GN (2015) Assessment of the population structure and temporal changes in spatial dynamics and genetic characteristics of Atlantic bluefin tuna under a fishery independent framework. Doctoral Thesis Submitted to Alma Mater Studiorum-Università di Bologna \& Universiteit Gent, 237 p. http://www.iccat.int/GBYP/Documents/BIOLOGICAL\%20STUDIES/Scientific_ Papers/Puncher_PhD_Thesis.pdf

Puncher GN, Cariani A, Maes GE, Van Houdt J, Herten K, Cannas R et al (2018) Spatial dynamics and mixing of bluefin tuna in the Atlantic Ocean and Mediterranean Sea revéales using nexgeneration sequencing. Mol Ecol Resour. https://doi.org/10.1111/1755-0998.12764

Quílez-Badia G, Cermeño P, Sainz Trápaga S, Tudela S, Di Natale A, Idrissi M, Abid N (2013) 2012 ICCAT-GBYP pop-up tagging activity, in Larache (Morocco). Col Vol Sci Pap ICCAT 69:869-877

Ravier C, Fromentin JM (2001) Long-term fluctuations in the eastern Atlantic and Mediterranean bluefin tuna population. ICES J Mar Sci 58:1299-1317 
Ravier C, Fromentin JM (2004) Are long-term fluctuations in Atlantic bluefin tuna (Thunnus thynnus) populations related to environmental changes? Fish Oceanogr 13:145-160

Reglero P, Ciannelli L, Álvarez-Berastegui D, Balbín R, López-Jurado JL, Alemany F (2012) Geographically and environmentally driven spawning distributions of tuna species in the western Mediterranean Sea. Mar Ecol Progr Ser 463:273-284. https://doi.org/10.3354/meps09800

Restrepo VR, Díaz GA, Walter JF, Neilson J, Campana SE, Secor D, Wingate RL (2010) Updated estimate of the growth curve of western Atlantic bluefin tuna. Aquat Living Resour 23:335-342

Rey JC (1979) Interactions des populations de thon rouge (Thunnus thynnus) entre 1'Atlantique et la Mediterranée. In: Bard FX, Le Gall JY (eds) Le thon rouge en Mediterranée: Biologie, Pêche et Aquaculture. Actes Colloq 8:87-103

Rey JC, Cort JL (1986) The tagging of the bluefin tuna (Thunnus thynnus) in the Mediterranean: history and analysis. CIESM, $2 \mathrm{p}$

Richardson DE, Marancik KE, Guyon JR, Lutcavage ME, Galuardi B, Lam CH, Walsh HJ, Wildes S, Yates DA, Hare JA (2016) Discovery of spawning ground reveals diverse migration strategies in Atlantic bluefin tuna (Thunnus thynnus). PNAS 113(12):3299-3304

Ríos Jiménez S (2007) La gran empresa almadrabero conservera andaluza entre 1919 y 1936: el nacimiento del Consorcio Nacional Almadrabero. Historia Agraria 41:57-82

Rodríguez-Marín E, Clear N, Cort JL, Megalofonou P, Neilson J, Neves dos Santos M, Olafsdottir D, Rodríguez-Cabello C, Ruiz M, Valeiras X (2007) Report of the 2006 ICCAT workshop for bluefin tuna direct ageing. Col Vol Sci Pap ICCAT 60:1349-1392

Rodríguez-Roda J (1957) El crecimiento relativo del atún (Thunnus thynnus (L.) de Barbate. Inv Pesq 12

Rodríguez-Roda J (1962) Talla, peso, edad y crecimiento del atún del golfo de Cádiz, España. Actas de la reunión científica mundial sobre biología del atún y especies afines. FAO Fish Rep 6 3:1823-1834

Rodríguez-Roda J (1964) Biología del atún, Thunnus thynnus (L.), de la costa sudatlántica española. Inv Pesq 25:33-146

Rodríguez-Roda J (1967) Fecundidad de atún, Thunnus thynnus (L.), de la costa sudatlántica española. Inv Pesq 31(1):33-52

Rodríguez-Roda J (1969a) Resultados de nuestras marcaciones de atunes en el golfo de Cádiz durante los años 1960-1967. Publ Tec Junt Est Pesca 8:153-158

Rodríguez-Roda J (1969b) Los atunes jóvenes y el problema de sus capturas masivas. Publicaciones Técnicas de la Junta de Estudios de Pesca. Subsecretaría de la Marina Mercante, 8:159-162

Rodríguez-Roda J (1978) Rendimiento de las almadrabas del sur de España durante los años 1962-1977, en la pesca del atún, Thunnus thynnus (L.). Inv Pesq 42(2):443-454

Rodríguez-Roda J (1980) Description of the Spanish bluefin (Thunnus thynnus) trap fishery. Col Vol Sci Pap ICCAT 11:180-183

Rooker J, Alvarado J, Block B, Dewar H, De Metrio G, Prince E, Rodríguez-Marín E, Secor D (2007) Life and stock structure of Atlantic bluefin tuna (Thunnus thynnus). Rev Fish Sci 15:265-310

Rooker J, Arrizabalaga H, Fraile I, Secor DH, Dettman DL, Abid N, Addis P, Deguara S, Karakulak FS, Kimoto A, Sakai O, Macias D, Santos MN (2014) Crossing the line: migratory and homing behaviours of Atlantic bluefin tuna. Mar Ecol Prog Ser 504:265-276

Ross M (2010) The glory days of the giant Scarborough tunny. British Library Cataloguing in Publication Data, 390 p. ISBN 978-0-9566375-0-5

Rouyer T, Brisset B, Bonhommeau S, Fromentin JM (2018) Update of the abundance index for juvenile fish derived from aerial surveys of bluefin tuna in the western Mediterranean Sea. Col Vol Sci Pap ICCAT 74(6):2887-2902

Santamaria N, Acone F, Di Summa A, Gentile R, Deflorio M, De Metrio G (2003) Età ed accrescimento di giovanili di tonno rosso (Thunnus thynnus L. 1758) nei mari meriodionali d'Italia. Biol Mar Medit 10(2):900-903

Sáñez A (1791) Diccionario histórico de las artes de pesca nacional por el Comisario Real de Guerra de Marina, 1791-1795, Madrid, 1988 
Sarà G, Sarà R (2007) Feeding habits and trophic levels of bluefin tuna Thunnus thynnus of different size classes in the Mediterranean Sea. J Appl Ichthyol 23(2):122-127

Sella M (1929) Migrazioni e habitat del tonno (Thunnus thynnus) studiati col metodo degli ami, con osservazioni ull'accrescimento, sul regime delle tonnare, ecc. Memorie, R. Comitato Talassografico Italiano 159:1-24

Sorell JM, Varela JL, Goñi N, Macías D, Arrizabalaga H, Medina A (2017) Diet and consumption rate of Atlantic bluefin tuna (Thunnus thynnus) in the Strait of Gibraltar. Fish Res 188:112-120

Suzuki Z, Kai M (2012) Movement of Atlantic bluefin tuna toward the Strait of Gibraltar inferred from Japanese longline data. Col Vol Sci Pap ICCAT 67:322-330

Tangen M (1999) Størjefisket på vestlandet. Eide forlag 1.3.3 Bergen. Trykk og innbinding: Valdres Trykkeri. Repro Øyvind Tangen. ISBN 82-514-0586-6

Tangen M (2009) The Norwegian fishery for Atlantic bluefin tuna. Col Vol Sci Pap ICCAT 63:79-93

Tensek S, Pagá García A, Di Natale A (2018) ICCAT GBYP tagging activities in phase 6. Col Vol Sci Pap ICCAT 74(6):2861-2872

Tiews K (1978) On the disappearance of bluefin tuna in the North Sea and its ecological implications for herring and mackerel. Rapp P-v Reun Cons Int Expl Mer 172:301-309

Tsuji S, Nishikawa Y, Segawa K, Hiroe Y (1997) Distribution and abundance of Thunnus larvae and their relation to the oceanographic condition in the Gulf of Mexico and the Mediterranean Sea during May through August of 1994 (Draft). Col Vol Sci Pap ICCAT 46:161-176

Vanderlaan A, Jech JM, Weber TC, Rzhanov Y, Lutcavage M (2014) Direct assessment of juveniles Atlantic bluefin tuna: integrating sonar and aerial results in support of fishery independent surveys. Col Vol Sci Pap ICCAT 71(4):1617-1625

Vilela H, Cadima E (1961) Études sur les thons, Thunnus thynnus (L.) de la côte Portugaise. Ann Biol Cons Int Expl Mer 16:241-245

Wilson SG, Block B (2009) Habitat use in Atlantic bluefin tuna Thunnus thynnus inferred from diving behaviour. Endang Species Res 10:355-367

Open Access This chapter is licensed under the terms of the Creative Commons Attribution 4.0 International License (http://creativecommons.org/licenses/by/4.0/), which permits use, sharing, adaptation, distribution and reproduction in any medium or format, as long as you give appropriate credit to the original author(s) and the source, provide a link to the Creative Commons license and indicate if changes were made.

The images or other third party material in this chapter are included in the chapter's Creative Commons license, unless indicated otherwise in a credit line to the material. If material is not included in the chapter's Creative Commons license and your intended use is not permitted by statutory regulation or exceeds the permitted use, you will need to obtain permission directly from the copyright holder.

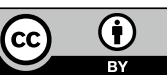

